\title{
ECOTURISMO: ASPECTOS CONCEITUAIS, REFLEXÕES E DIRETRIZES PARA PROJETOS PAISAGÍSTICOS
}

\author{
ECOTOURISM: CONCEPTS, REFLECTIONS AND GUIDELINES \\ FOR LANDSCAPE PROJECTS
}

\author{
Luis Guilherme A. Pippi \\ Arquiteto e urbanista, mestre em Desenho Urbano e Paisagem pela UFSC e professor assistente da \\ Universidade Federal de Santa Maria no curso de Arquitetura e Urbanismo Campus da UFSM - Curso \\ de Arquitetura e Urbanismo - CAU - Camobi - RS \\ e-mail: guiamy@hotmail.com
}

\section{Lucienne Rossi Lopes Limberger}

Arquiteta e urbanista, mestre em Planejamento Urbano e Regional pela UFRGS e professora assistente da Universidade Federal de Santa Maria no curso de Arquitetura e Urbanismo. Campus da UFSM - curso de Arquitetura e Urbanismo - CAU - Camobi - RS

e-mail: lulimbe@smail.ufsm.br

\section{Gerusa Lazarotto}

Arquiteta e urbanista, egressa da Universidade Federal de Santa Maria no curso de Arquitetura e Urbanismo Campus da UFSM - curso de Arquitetura e Urbanismo - CAU - Camobi - RS

e-mail: gelazarotto@yahoo.com.br

\section{RESUMO}

O ecoturismo nos oferece a oportunidade de garantir a conservação dos ecossistemas naturais e a qualificação de um ambiente, respeitando a natureza de um patrimônio natural ou de um ambiente com potencialidades ambientais e paisagísticas. $\bigcirc$ presente estudo tem como objetivo expor alguns conceitos e diretrizes relacionadas ao ecoturismo, de maneira a auxiliar todos os envolvidos, diretos ou indiretamente, no processo de concepção e manutenção das Áreas de Preservação Ambiental. A análise faz uma abordagem sobre a articulação de seus objetivos principais com suas estratégias projetuais.

No projeto dessa modalidade alternativa de turismo, cabe, aos autores dos projetos paisagísticos, a aplicação de metodologias para o diagnóstico e interpretação da paisagem, a utilização da sensibilidade criativa aliada às técnicas alternativas e o conhecimento de materiais para a implantação de estruturas físicas e paisagísiticas, possibilitando, aos usuários ecoturísticos e à comunidade local, o despertar da conscientização ambiental e a conservação e preservação do patrimônio natural e cultural de uma determinada região.

Palavras-chave: Ecoturismo, diretrizes projetuais paisagísticas, sustentabilidade ambiental.

\begin{abstract}
This study aims to expound some concepts and guidelines within the area of ecotourism, in order to aid all those involved in the area, both directly and indirectly, in the process of conception and maintenance of Areas of Environmental Preservation. The analysis deals with the articulation of main objectives and project strategies.

In alternative tourism projects, application of methodologies of diagnosis and interpretation, as well as creative sensibility and knowledge of landscape building materials are all necessary in order to conserve the natural and cultural heritage of a region and provide the community and ecotourist with an awakening of environmental consciousness.
\end{abstract}

Key words: Ecoturism, landscape project guidelines, environmental sustainability. 


\section{INTRODUÇÃO}

Na última década, no Brasil e em todo o mundo, o ecoturismo, modalidade de turismo alternativo, está em crescimento progressivo, como oposição ao turismo de massa, agregando um número cada vez maior de adeptos e de lugares onde se possa "aproveitar" as maravilhas da natureza, mas com uma estrutura logística adequada. Considerando que a natureza é hoje um dos principais atrativos para a atividade turística, é necessária a preocupação constante com a manutenção do meio ambiente. $\bigcirc$ mesmo pode vir a contribuir para o desenvolvimento, de maneira positiva e conservacionista, incorporando, em seu projeto e manejo, estratégias baseadas em métodos de planejamento e materiais alternativos. Mas, em contrapartida, se o turismo ecológico não for bem planejado, implantado e controlado, pode vir a causar diversos problemas e impactos destrutivos sobre o meio ambiente.

Brasil é um dos países com maior potencial para a prática do ecoturismo, devido à grande diversidade e exuberância de suas paisagens. Essa modalidade de turismo está começando a difundir-se, em várias regiões de nosso país, como uma forma de manter suas qualidades naturais e ecológicas de maneira integrada, oferecendo a oportunidade de garantir a qualificação ambiental e a conservação e preservação dos ecossistemas naturais e a vitalidade de suas paisagens, quando incorporam, em seu manejo, as diretrizes ecoturísticas, aliadas ao planejamento e ao projeto paisagístico. A contribuição da arquitetura paisagística para com o ecoturismo está no diagnóstico e planejamento da paisagem, bem como o usufruto dos fenômenos naturais, aliados à escolha adequada dos materiais e soluções projetuais a serem utilizadas nas estruturas físicas das unidades de conservação, de forma que haja uma maior integração do projeto na paisagística com os recursos naturais às práticas ecoturísticas.

O presente artigo se propõe a auxiliar todos os envolvidos, direta ou indiretamente, no processo de concepção e manutenção de Áreas de Preservação Ambiental. Para tanto, em um primeiro momento, pretende-se analisar os conceitos e ilustrar as diretrizes e os objetivos dessa modalidade turística, possibilitando proteger o meio ambiente natural e cultural de uma determinada região, pela introdução dessa atividade em ecossistemas, com potencial ambiental e paisagístico (mar, lagoas, mangues, banhados, rios, córregos, encostas, falésias, mata atlântica, dunas, restingas, nascentes), permitindo criar base local para as Unidades de Conservação, como, por exemplo: parques nacionais, parques estaduais, áreas de proteção ambiental, florestas nacionais, parques ambientais municipais, entre outros.

Assim, entendemos que por trás dessa modalidade de turismo sustentável existe uma série de princípios ecológicos, que buscam garantir a sobrevivência econômica para o local, ao mesmo tempo em que beneficiam a população e o meio ambiente garantindo, assim, a perpetuação de suas atividades no presente e futuro. 


\section{HISTÓRICO DO ECOTURISMO}

Para Ruano (1999), o turismo é a indústria mais importante do mundo, uma vez que a mesma age direta e indiretamente sobre cerca de 10,7\% do produto interno global econômico, proporcionando cerca de $11 \%$ de todos os empregos existentes no mundo. Em contrapartida, essas atividades turísticas ocasionam os maiores índices de crescimento de densidade populacional, as massivas destruições paisagísticas promovidas pela massificação das edificações e descaracterização e impactos sobre o patrimônio natural e cultural. Somente nessa década foram iniciadas as primeiras estratégias mundiais de conservação e/ou preservação do ambiente natural, baseadas na necessidade de vincular-se o manejo das áreas protegidas com as atividades das comunidades locais. Após as conferências de Estocolmo (1972) e da Eco-92 no Rio de Janeiro (movimento ecológico e do meio ambiente), despertou-se a consciência ambiental.

Segundo Lindberg e Hawkins (1999), o ecoturismo se originou das intenções mundiais conservacionistas, de maneira mais evolutiva do que revolucionária. Suas raízes estão calcadas na natureza e no turismo ao ar livre. $\bigcirc$ mesmo surgiu nos anos 70 como uma modalidade turística alternativa capaz de mitigar os impactos ambientais negativos, promover o desenvolvimento ecológico integrado pela exploração adequada das potencialidades dos atrativos naturais e propiciar um meio de abertura ao crescimento econômico, bem como a aplicação dos princípios ambientais concervacionistas e preservacionistas, valorizando o patrimônio natural, incentivando a responsabilidade social (órgãos competentes, corpos técnicos, comunidade e turistas) e promovendo o envolvimento dos aspectos culturais em busca de uma economia equilibrada.

mesmo reapareceu com força nos anos 90 e continua se expandindo até os dias atuais, como uma forma de oposição ao crescimento do turismo em massa e à insustentabilidade de uma região. Seus principais usuários são: excursões, grupos escolares, visitantes individuais, mochileiros, campistas, cientistas, pesquisadores, colecionadores, fotógrafos (amadores e profissionais), praticantes de atividades náuticas, mergulhadores, naturalistas, aventureiros, observadores da fauna e flora e outros.

Para Lindberg e Hawkins (1999, p. 17), o interesse crescente pelo ecoturismo entre os governantes dos países em desenvolvimento, os operadores comerciais, as organizações assistenciais e os conservacionistas dá a dimensão de seu enorme potencial econômico e conservacional. Os ecoturistas gastam bilhões de dólares todos os anos. Mas a importância do ecoturismo vai muito além desses números. Os ecoturistas gostam de utilizar os recursos e a mão-de-obra local. Isso se traduz em entrada de divisas do exterior, projetos adequados ao meio-ambiente e engajamento dos moradores da região na indústria de viagens. A ênfase do ecoturismo nos recursos locais e no emprego de mão-de-obra da região torna-o uma opção atraente para os países em desenvolvimento. Países ricos em áreas naturais, mas em 
situação desfavorável, dada a pobreza rural e a ausência de receitas de exportação, são bons exemplos. $\bigcirc$ ecoturismo pode provocar e satisfazer o desejo de estar em contato com a natureza, explorando o potencial turístico visando à conservação e/ ou preservação ambiental e o desenvolvimento da ecologia, a cultura e a estética da paisagem.

Esse novo caminho se configura como o início da introdução de novas urbanizações turísticas que incorporam os temas ecológicos aliados à experimentação de conceitos e técnicas alternativas inovadoras, capazes de garantir a sobrevida do meio ambiente natural (RUANO, 1999).

\section{CONCEITUAÇÃO, OBJETIVOS, ESTRATÉGIAS E DIRETRIZES DO ECOTURISMO}

Segundo a Embratur (1995), "O ecoturismo é o segmento da atividade turística que utiliza, de forma sustentável, o patrimônio natural e cultural, incentiva sua conservação e busca a formação de uma consciência ambientalista através da interpretação do ambiente, promovendo o bem-estar das populações envolvidas".

Para entendermos melhor a complexidade envolvida na palavra ecoturismo, precisamos conceituar o termo ecologia, que, segundo Adam (2001), significa o estudo do hábitat, da relação entre os seres e este último. Entendendo os humanos como parte integrante do meio ambiente natural, onde se percebe o universo não como um conjunto de objetos isolados, mas como uma teia de fenômenos interconectados e interdependentes.

A ambigüidade do ecoturismo reflete as diferenças entre seu conceito e a mercantilização da natureza, isto é, sua transformação em um produto vendável, oferecido pelo marketing, com fins apenas consumistas. Essa política desordenada é impulsionada pela oportunidade do mercado de negócios. Na verdade, o ecoturismo é um fenômeno muito complexo, pois o mesmo pode ser interpretado conforme diferentes vertentes, dentro do universo ambientalista, bem como no universo dos negócios. Existem diversas segmentações provindas do ecoturismo, para atrair a clientela amadora ou profissional, por meio de observação (paisagem natural, fauna e flora), pesca esportiva, pesquisas científicas, prática de aventura e esportivas (canoagem, treking e rafting).

$\bigcirc$ ecoturismo, apesar dessa ambigüidade, oferece a possibilidade alternativa de combater-se os impactos negativos sobre o meio ambiente, ecologia, cultura e estética de um determinado lugar. $\bigcirc$ mesmo explora o potencial natural de um determinado lugar pela conservação e/ou preservação dos recursos naturais e da implementação de um desenvolvimento ecológico integrado.

Lindberg e Hawkins (1999) consideram o ecoturismo como um fenômeno complexo e multidisciplinar, pelos quais muitos aspectos devem ser levados em conta, a fim de ele ser um empreendimento bem-sucedido para todos os envolvidos: consumidores, administradores, povos nativos, fornecedores e profissionais técnicos. Para isso faz-se necessária a aplicação de inventários sistemáticos e detalhados das atrações ecoturísticas 
e sua integração com as instalações das estruturas físicas (edificações, infra-estrutura e áreas livres de edificação) e com as áreas naturais em suas proximidades são fundamentais para o desenvolvimento do ecoturismo.

Planejamento, projeto e critérios de construção adequados devem ser aplicados, a fim de minimizar os impactos sobre o meio ambiente, fornecer certo grau de auto-suficiência funcional e contribuir para a melhoria da qualidade da experiência dos visitantes. Infelizmente, não existem centros de interpretações da natureza, conhecidos também como centros de visitantes, na maior parte das unidades de conservação. Dessa forma faz-se necessário um cuidado especializado para que as instalações sejam acolhedoras, pedagogicamente apropriadas, de fácil operação e manutenção, e correspondendo à realidade socioeconômica local (LINDBERG; HAWKINS, 1999).

Conforme Boullón (2002), existem diversos profissionais que atuam no campo do projeto das estruturas físicas nas unidades de conservação, investindo o conhecimento científico e técnico de diversas áreas de conhecimento, cuja finalidade é o planejamento físico territorial e o ordenamento das ações humanas sobre o território. Isso só será possível se houver uma participação multi e interdisciplinar de profissionais como: arquitetos paisagistas, topógrafos, geógrafos, geólogos, meteorologistas, oceanógrafos, especialistas em estudo do solo, engenheiros agrônomos, sanitaristas e florestais, planejadores urbanos, planejadores da paisagem, ecologistas, biólogos, sociólogos, biólogos, entre outros.

A linguagem do planejamento do território, para as práticas ecoturísticas, maneja sete tipos diferentes de espaço físico (real, potencial, cultural, natural, virgem, artificial e vital). Alguns desses correspondem a diferentes expressões materiais do espaço físico (cultural, natural, virgem e artificial), outros são qualificações conceituais próprias do planejamento da paisagem e de suas unidades e elementos (real e potencial) e um deles pertencente ao campo da ecologia (vital) - Boullón (2002).

"A paisagem é considerada como um produto e como um sistema: como um produto porque é o resultado de um processo social de ocupação e gestão de um território; e como um sistema, na medida que a partir de qualquer ação sobre ela impressa, com certeza haverá uma reação correspondente, no caso equivalendo ao surgimento de uma alteração morfológica parcial ou total." (MACEDO, 1999, p. 11)

Para Johnson (1997), sustentabilidade e estética são princípios que devem ser levados em consideração ao projetar-se a paisagem. Sustentabilidade, porque, pela consideração dos processos ecológicos no planejamento paisagístico, podem-se incorporar os processos naturais para a restauração das funções naturais para o meio ambiente. Devem ser usadas novas tecnologias, como o uso da ecogênese, que promovam a recuperação ambiental de áreas degradadas. A estética deve ser introduzida como uma ferramenta a valorizar os processos ecológicos de restauração da paisagem, promovendo a beleza dos processos naturais na cidade os quais podem reforçar a introdução da educação ambiental na comunidade, e, assim, fomentar uma maior participação perante essa, pelo desejo de valorizar, cuidar e manter. 
arquiteto paisagista se insere no campo ecoturístico, fornecendo sua contribuição por meio de seu conhecimento técnico e habilidades de projetar os ambientes naturais, garantindo sua funcionalidade e a inter-relação entre as partes, de maneira a unificar toda a estrutura física (edificações e áreas livres) com os atrativos locais.

Como, por exemplo, a paisagem e seus elementos constituintes, promovidos pela integração por meio de: altura das construções, relação transitória entre interior e exterior das edificações, uso de materiais locais e técnicas alternativas nas construções/ equipamentos/instalações/infra-estrutura, levantamento e planejamento ecológico e diagnóstico da paisagem, recuperação das áreas degradadas, planejamento físico, policromia da paisagem, plano de manejo, mapas temáticos, educação ambiental, entre outros. Em muitos casos, essas habilidades técnicas são compartilhadas com outros profissionais, mencionados anteriormente, buscando-se, assim, a concretização dos objetivos do ecoturismo.

Conforme a Embratur (1995), "Os objetivos correspondentes ao turismo ecológico ou ecoturismo são: compatibilizar as atividades de ecoturismo com a conservação das áreas naturais; fortalecer a cooperação interinstitucional; possibilitar a participação efetiva de todos os segmentos atuantes no setor; promover e estimular a capacitação de recursos humanos para o ecoturismo; promover, incentivar e estimular a criação e melhoria da infra-estrutura para a atividade do ecoturismo, promover o aproveitamento do ecoturismo como veículo de educação ambiental".

Cabe destacar a legislação pertinente para as Unidades de Conservação, Áreas de Preservação Permanente (APPs) e suas relações com as práticas ecoturísticas, no que tange à aplicação de suas diretrizes, objetivos e usos, o plano de manejo das áreas naturais e a implantação de estruturas físicas, amparadas por:

- Lei federal (Lei n. 9.985 de 2000 - Sistema Nacional de Unidades de Conservação - SNUC); e as Áreas de Preservação Permanente (APPs);

- legislação federal (Lei n. 4771 de 1965 - Código Florestal);

- resoluções do Conama (Lei n. 369 de 2006 - dispõe sobre os casos excepcionais, de utilidade pública, interesse social ou baixo impacto ambiental, possibilitando o uso para o ecoturismo em Área de Preservação Permanente - APP e Lei n. 302, de 2002, que dispõem de diretrizes para implantação de equipamentos em Área de Preservação Permanente - APP, para práticas ecoturísticas).

Segundo a Embratur (1995), "As estratégias de planejamento do ecoturismo consiste em: regulamentação do ecoturismo; fortalecimento e interação institucional; formação e capacitação de recursos humanos; controle da qualidade do produto ecoturístico; gerenciamento de informações; incentivos ao desenvolvimento do ecoturismo; implantação e adequação da infra-estrutura; conscientização e informação ao turista; participação comunitária".

Dentre algumas das estratégias e diretrizes ecoturísticas principais, podemos citar:

- O zoneamento ecológico e o saneamento ambiental;

- a recuperação e conservação do meio ambiente conforme as necessidades da comunidade local e sua sensibilidade ao meio ambiente; 
- o planejamento de um desenvolvimento turístico ecológico;

- a educação ambiental.

Para que as diretrizes do turismo ambiental tenham eficiência, é preciso levar em consideração os tipos de visitantes, considerando-se o número, o tempo de estadia no local, a tolerância do local e sua vulnerabilidade quanto aos impactos e perturbações originados pelos usuários (locais e turistas).

Também é preciso implementar um sistema integrado e participativo atendendo a todos os setores na elaboração das diretrizes ecoturísticas: comunidade, empresas privadas, organizações sem fins lucrativos, guias turísticos, intérpretes, autoridades governamentais e órgãos nacionais e locais, indústria do turismo (operadores) e técnicos.

Podemos entender melhor o universo do ecoturismo, conforme o esquema abaixo:

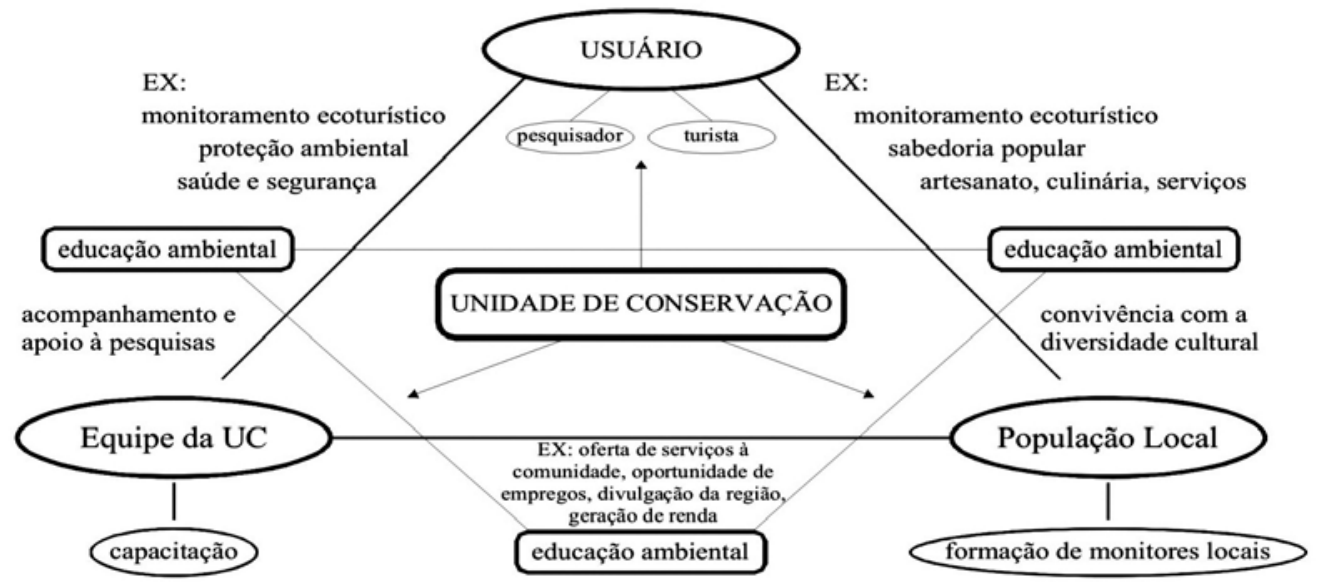

Quadro 1: Quadro esquemático estruturador das Unidades de Conservação com a educação ambiental Fonte: FIGUEIREDO, 1997

A incorporação adequada das estratégias e diretrizes ecoturísticas pode contribuir para garantir a sustentabilidade das Unidades de Conservação. Para isso é preciso a incorporação de um sistema integrado que envolva os usuários ecoturísticos, a equipe das Unidades de Conservação e a população local, promovendo a educação ambiental. O plano de manejo formulado a partir de proposições no âmbito da arquitetura paisagística, na configuração de ambientes que propiciem o monitoramento ecoturístico, a proteção ambiental, o apoio a pesquisas científicas, a perpetuação da cultura local e econômica, pela oferta de empregos.

Além dessas diretrizes ambientais, podemos ainda incentivar a criação de diretrizes sociais e econômicas, para assim reforçar a sustentabilidade do local, pela compra de produtos locais (mudas, artesanato, arte e alimentos produzidos); pagamento de serviços e ingressos; doações para entidades locais sem fins lucrativos; uso de restaurantes e alojamentos de propriedade local e comportamento adequado quanto às gorjetas. 


\section{PROBLEMAS DIVERSIFICADOS}

"Apesar da valiosa biodiversidade natural, o Brasil só protege 1,85\% de sua área, enquanto a média mundial é de $6 \%$. E o pouco que se protege está muito mal administrado - quando não completamente abandonado, vulnerável à ação de vândalos e da exploração clandestina das riquezas naturais. (CALDAS, 1999). Nosso Governo investe poucos recursos financeiros na manutenção e conservação das Unidades de Consrevação. A inexistência de infra-estrutura de manutenção e fiscalização facilita usos inadequados das áreas e só reforça a degradação ambiental e consequentemente a perda dos atrativos naturais ecoturísticos." (VIVEIROS, 2003, p. C1).

"CALDAS (1999, p. 39) afirma que somente 2 milhões de pessoas visitam nossas unidades de conservação anualmente. Apenas por comparação: o Sistema Nacional de Parques dos EUA recebe milhões de visitantes, que geram 10 bilhões de dólares e dão emprego a 200.000 pessoas. Até "as selvas da Costa Rica, na América Central, atraem mais ecoturistas que o colosso amazônico". Não se pode importar fielmente o padrão americano para os nossos parques, pode-se tirar proveito dos seus princípios, tais como: respeitar e considerar as comunidades tradicionais que vivem dentro, ou próximos dos Parques; proporcionar empregos e infra-estrutura; promover a educação ambiental de toda a população."

A carência de profissionais capacitados em trabalhar com o planejamento da arquitetura da paisagem, a falta de controle por parte dos órgãos de planejamento, bem como a insuficiência de espaços públicos destinados ao lazer, recreação e à conservação ambiental desencadeiam diversos desequilíbrios sociais e ambientais.

Umas das formas de reverter-se esse processo é efetivar novos empregos, nos quais diversas competências técnicas de profissionais de diversas áreas de conhecimento, especialistas no planejamento ecológico das paisagens, dentre esses os paisagistas, podem vir a contribuir de forma positiva para atuar nas Unidades de Conservação, seja no diagnóstico e planejamento da paisagem, seja na formulação do plano de manejo e no projeto arquitetônico e paisagístico das estruturas físicas, promovendo a sustentabilidade ambiental e paisagística das práticas ecoturísticas ao oferecer condições tais como: funcionalidade, desenvolvimento econômico, saneamento básico, conforto, higiene, saúde, convívio social, convívio com a natureza, a serem promovidas a médio e longo prazos.

\section{DIRETRIZES, ESTRATÉGIAS E PLANEJAMENTO \\ DO CAMPO DA ARQUITETURA PAISAGÍSTICA \\ E SUA CONTRIBUIÇÃO ÀS PRÁTICAS ECOTURÍSTICAS}

A seguir será apresentada a metodologia adotada para a implantação de diretrizes, estratégias e planejamento para a prática do ecoturismo em Unidades de Conservação, e sua relação direta com o projeto arquitetônico e paisagístico. 


\section{Diretrizes paisagísticas}

Para qualquer tipo de intervenções antrópicas sobre a paisagem deve-se levar em consideração os aspectos biofísicos e os condicionantes socioculturais, funcionais e estéticos de uma região. No planejamento do ambiente natural é primordial considerar, de maneira integrada, o solo, a água, as plantas, os animais e a população concernida. Com isso, melhora a identidade de suas paisagens.

A arquitetura paisagística oferece os instrumentos de análise e interpretação da paisagem (leitura, percepção, planejamento e aplicação de sensações no tratamento da paisagem), verificando como esses podem auxiliar na elaboração de diretrizes para o planejamento dos espaços livres, possibilitando o desenvolvimento de projetos de urbanismo, arquitetura e paisagismo coerente com as necessidades e potencialidades de cada região, o que pode vir a contribuir para a inserção correta das práticas ecoturísticas.

Primeiramente, é preciso se fazer uma análise completa e constante da paisagem (suas unidades, elementos e características), das belezas naturais, do funcionamento de seus ecossistemas naturais e dos impactos ambientais já existentes no local, para serem formuladas estratégias e diretrizes que possam acabar ou minimizar os problemas e, assim, garantir a conservação dos recursos naturais e a garantia do bem-estar da comunidade local.

Segundo Abbud (2006) e Sattler (2004), por meio do projeto de paisagismo sobre as áreas naturais e paisagens presentes nas Unidades de Conservação, consegue-se aplicar o conhecimento técnico aliado à expressão artística, em que participam os cinco sentidos do ser humano. O paisagismo envolve também o olfato, a audição, o paladar e o tato, o que proporciona uma rica vivência sensorial e pedagógica (educação ambiental), ao somar as mais diversas experiências perceptivas aos usuários, ao contemplarem a paisagem natural e seus fenômenos de maneira mais intensa e completa, por meio de recantos de parada (clareiras, mirantes, passarelas e trilhas), entorno externo às edificações. Cada paisagem possui diferentes sons, cheiros e texturas. Palavras, desenhos, pinturas, fotografias ou vídeo não podem substituir a experiência dos fenômenos naturais de um determinado lugar por seus visitantes, pois sempre se transformam devido à sua dinâmica. É por meio delas que talvez possa ser realçada a experiência pelos atrativos naturais, por meio de sensações e até mesmo inspirar a criação de paisagens. A autora ainda considera que o diálogo com o vento, a água, a luz, as plantas, os animais, a humanidade e outros podem e devem ser fomentados, estimulando idéias para estabelecer uma linguagem e um diálogo harmônicos com a paisagem, proporcionadas pelo projeto paisagístico (SPIRN, 1998, tradução nossa).

Os princípios fundamentais à humanização e valorização da paisagem nas cidades brasileiras surgiu no modernismo do século 20. Destacando-se a atuação de profissionais como Burle Marx, que estudava os repertórios florais com a mesma "sensibilidade do artista" a acompanhar todas as nuances da luz solar sobre o colorido da vegetação policromia. A intenção do artista é pôr em evidência a beleza das cores e das formas, do ritmo, das texturas e dos volumes ordenados, estabelecendo harmonias, criando 
contrastes, trabalhando o conjunto como uma trama de elementos, todos indispensáveis para a paisagem adquirir a plenitude de seu significado e proporcione reflexões.

Por meio da policromia é possível integrar-se ao meio natural e suas paisagens pelo tratamento das superfícies, texturas, uso de cores presentes na combinação paisagística da vegetação, materiais e superfícies das edificações e infra-estruturas verdes propostas. Seu legado paisagístico valoriza a paisagem circundante, realçada pela disposição dos caminhos (percurso e sinuosidade), do mobiliário urbano (com plasticidade vigorosa), permitindo, ao percorrer esses ambientes, sensações de surpresas e surpreendentes perspectivas, bem como a contemplação e desfrute da paisagem.

Para Abbud (2006) e Sattler (2004), através da visão focalizam-se os elementos vegetais, percebidos pela copas, flores, frutos, folhas, troncos/caules e galhos, desde seu formato, como sua policromia e textura, bem como o aspecto visual configurado pelas combinações vegetais utilizadas na configuração dos ambientes. Os recursos naturais, como o vento e o sol, proporcionam maior dinamismo às sensações ao longo do dia/ noite e estações do ano. $\bigcirc$ tato propicia um contato direto com os elementos naturais, pela rugosidade, lisura, aspereza, maciez ou dureza dos materiais, o que pode ser reforçado pelo calor do sol e sombreamento (sensações de calor ou frio), a utilização de diferentes texturas contribui para a criação de um ambiente estimulante e contrastante, harmônico para o tato. A audição é outro condicionante sensorial bastante utilizado, tanto em ambientes internos como externos, nos quais é possível vivenciar os sons da natureza e seus fenômenos naturais, bem como de seus personagens (animais, insetos e vegetações). $\bigcirc$ paladar possibilita o conhecimento dos espaços ajardinados pelas flores e frutos comestíveis, podendo atrair também pássaros e fauna local; para maior integração com o meio natural o ideal é utilizar espécies arbóreas frutíferas nativas. olfato, pelo cheiro da vegetação, configura o desfrute de perfumes exalados, pelas folhas, flores, frutos, cascas, ramos e madeira, o que podem ser exaltados com o sol e a chuva.

projeto de paisagismo pode vir a contribuir para o conforto térmico; pela disposição da vegetação (arbóreas e arbustivas) e de áreas permeáveis quando dispostas de forma adequada próximas às edificações e ambientes, e pode vir a contribuir como uma alternativa econômica para melhorar as condições de conforto térmico, como brises naturais, barreira contra o vento e insolação. Arbóreas, arbustivas e trepadeiras podem propiciar sombreamento nas fachadas das edificações, principalmente para as fenestrações a norte, leste e oeste. $\bigcirc$ ideal é escolher espécies decíduas, de modo a permitir a entrada de luz solar nos meses de inverno. Outra forma de obter-se conforto térmico nos ambientes edificados e abertos é o uso de pergolados e caramanchões e lajes jardim e/ou telhados verdes.

Para Abbud (2006), a utilização de matéria-prima diversificada é obtida dos elementos e condicionantes da natureza:

Ar: Elemento associado a diversos significados como a vida, o vento, aroma, transparência e movimento. Contribui para a conformação dos espaços, fundamentais à paisagem, bem como a promoção de sensações como som, movimento, leveza, ele- 
vação e suavidade.

Água: Elemento essencial na estrutura de todos os ecossistemas. Simboliza a fertilidade, força de vontade e adaptabilidade. Bastante utilizada nos projetos paisagísticos, representa a fonte da vida, uma vez que oferece o hábitat e alimento da fauna e flora, proporciona tranqüilidade, harmonia, paz e conforto térmico, pode servir como atrativo aos animais. A água pode estar ligada pelo sistema integrado de infra-estrutura verde (jardins de chuva, biovaletas, cisternas, lagoas de retenção).

Fogo: Relaciona tudo o que é pleno, brilhante e quente. Pode representar significados como calor, paixão, vibração, luz, vida, transformação, energia, ação, explosão, criação e propagação. Fornece luz, calor e aconchego durante a noite e inverno. Merece alguns cuidados especiais em relação ao meio ambiente natural (fogueiras, fogo-de-chão, churrasqueiras).

Terra: Simboliza a estabilidade, segurança e firmeza. Base para os projetos paisagísticos, uma vez que oferece o hábitat de todos os ecossistemas, representa a vida, o alimento, a cultura, a riqueza, o suporte e a paisagem.

Flora: Fator primordial ao projeto de paisagismo na configuração dos ambientes e recuperação ambiental.

Fauna: É atraído aos ambientes criados pelos projetos paisagísticos, contribui para a homeostase ecossistêmica dos elementos da paisagem.

Tempo: Evolução e transformação da paisagem ao longo dos anos, estações e dia/noite.

Para a permanência dos usuários do ecoturismo nos ambientes projetados e programados (recantos nas trilhas, passarelas, mirantes e clareiras), é fundamental a aplicação dos fundamentos que propiciem a experiência das sensações, envolvendo os mesmos e integrar os visitantes com a natureza, pela estimulação da permanência e prática de atividades, como descansar, meditar, ler, conversar, contemplar e observar o entorno e os elementos da paisagem.

\section{A paisagem e o espaço turístico}

O entendimento e a aplicação de conceitos como: planejamento ecológico da paisagem, sustentabilidade, ecoedifício, infra-estrutura verde é fundamental para dar subsídios aos projetos de arquitetura e paisagismo, buscando zonear e organizar os usos sobre o espaço geográfico a sofrer intervenção, e, conseqüentemente, garantir a integração entre a modalidade do ecoturismo com o meio ambiente natural e suas paisagens.

Outra forma de incrementar as análises ecoturísticas é implementar esse monitoramento do espaço geográfico e da qualidade da paisagem pela utilização de um Sistema Informações Geográficas (SIG), proporcionando uma visão de todo o conjunto ecoturístico sobre as Unidades de Conservação. No banco de dados, representadas no quadro acima, no qual se espacializa, estão todas as informações sobre o meio natural e as ações antrópicas sobre o mesmo (fixos, fluxos, objetos naturais e artificiais), para poder avaliar com maior precisão os impactos sobre a paisagem.

Esse sistema facilita a atualização das informações e contribui para o monitoramen- 


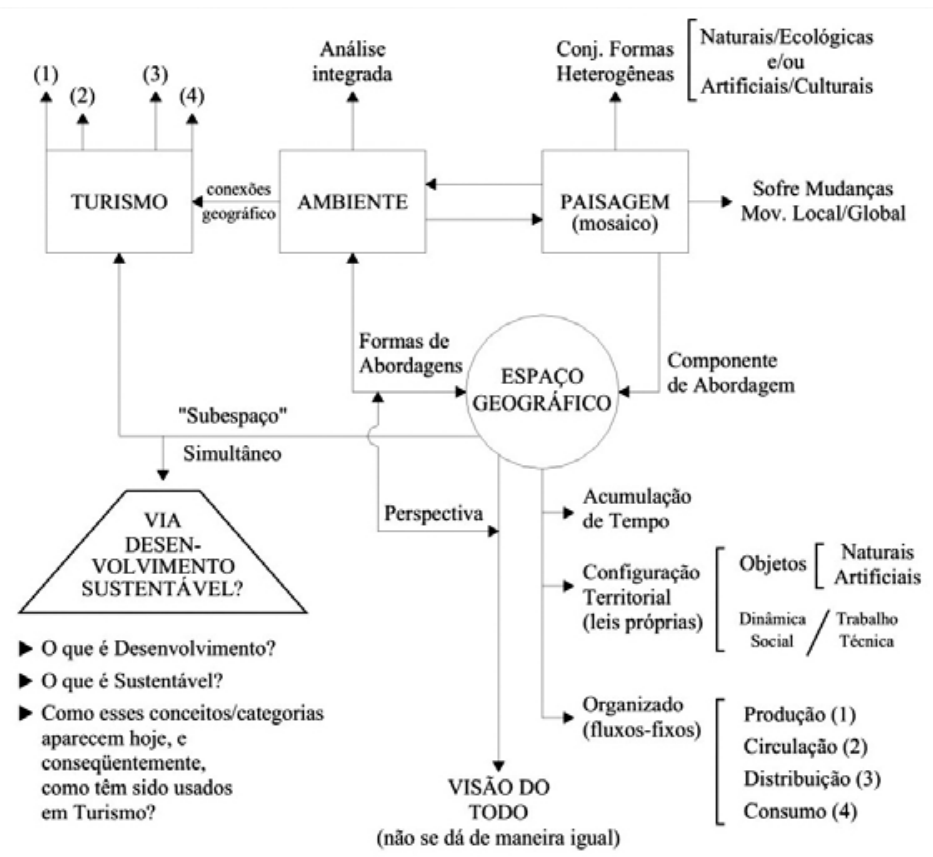

Figura 2: Quadro esquemático para a análise ecoturística

FONTE: MACHADO, 1997

to, permitindo o acompanhamento, a divulgação dos dados ambientais à comunidade (autoridades competentes, população local e turistas) e a proposição de diretrizes para a área, efetivando a prática de conservação e/ou recuperação das áreas mais carentes e/ou degradadas. A falta de informação e/ou compreensão global do espaço geográfico e da paisagem pode levar a muitos danos culturais e ambientais provocados pelos turistas, e, até mesmo, em algumas vezes, pela população local.

Muitas vezes, é preciso, com o projeto paisagístico, incrementar a percepção dos usuários sobre a paisagem e seus elementos, auxiliando na interpretação de suas qualidades e seus fenômenos, pela educação ambiental, uma vez que os conceitos de beleza, qualidade, variam de indivíduo para indivíduo ou conforme cada cultura. Segundo Boullòn (2002), na tentativa de diminuir as limitações do homem urbano para interpretar a paisagem, aprofundamo-nos em sua análise: existem quatro propriedades, as quais, somadas às variáveis dos elementos da paisagem que conferem sua qualidade estética, podem vir a facilitar sua descrição e visualização:

Diversidade: Depende da quantidade de componentes visualmente diferenciáveis dos diversos pontos de vista dos quais se pode contemplar a paisagem. Ideal para a configuração de percursos e mirantes.

Repetição: Destaca uma determinada forma ou configuração do ambiente natural a dominar a cena. Pode conformar dois tipos de paisagem: a que possui espécies repetidas (grupo de vegetação, rochas) e aquelas que possuem um elemento repetido (montanhas, rios), que, mesmo sendo visto como "pano de fundo", pode transformar-se na unidade de paisagem de destaque.

Unidade: Refere-se ao equilíbrio visual dos componentes de uma cena. Precisa-se 
de um nivelamento para facilitar a leitura da paisagem.

Mudança: Representa o contraste das diferentes matizes de uma paisagem, que pode variar conforme as estações do ano, horas do dia e fenômenos naturais (sol e chuva).

De acordo com Boullòn (2002), por mais complexa que seja uma paisagem, qualquer pessoa pode diferenciar seus caracteres, caso consigam obter uma informação adequada quanto à descrição e leitura da paisagem. Três fatores são essenciais para se decifrar a mesma: estrutura (distribuição e organização das partes integrantes do cenário natural), forma nítida (partes mais visíveis ou identificáveis possuem um destaque maior na qualificação da paisagem) e diferenciação (dos diversos elementos, bem como da dinâmica da paisagem).

Ainda conforme Boullòn (2002), os usuários podem ser conduzidos a apreciar tanto a paisagem aberta como a fechada, pois estas têm a estrutura, forma nítida e diferenciação. Na paisagem fechada é possível captar todas as manifestações do ambiente que as contém pelos estímulos sensoriais. Na paisagem aberta, o fator diferenciação é o mais importante, pois se pode ver tudo em um instante, mas sem apreciar os detalhes que aparecem na paisagem fechada. $\bigcirc$ ideal é propiciar ambientes os quais ofereçam sucessivos pontos com diferentes pontos visuais de observação, visão em série ou serial, com diferentes surpresas e sensações ao longo de seu percurso.

Para Boullòn (2002), o impacto visual que o ambiente natural produz varia de acordo com o tipo de atividade desenvolvida pelo turista, o que pode também diferenciar o foco de interpretação e leitura da paisagem e seus elementos constituintes, variando conforme as três classes de turistas:

Espectador: Mantém-se fora da paisagem e limita-se a observá-la dos diversos pontos de vista pela estrada ou pelos mirantes ao longo do caminho. Passa rapidamente pela paisagem e dificilmente lembrará desta.

Agente: Incorpora-se na paisagem para a prática de esportes ou circuito de aventura. Seu foco principal está na prática esportiva, ao invés da leitura e observação da paisagem. Geralmente, a paisagem se torna o pano de fundo, o qual pode propiciar alguma contemplação, seu registro na lembrança da paisagem será um pouco "apagado".

Agente-observador: Geralmente se refere ao tipo de visitante que entra e permanece na paisagem; o espectador se torna protagonista da paisagem, por ficar algumas horas ou vários dias no local, geralmente nas caminhadas, estudos de pesquisa e camping; bem como alguns turistas que praticam esportes ou atividades sedentárias (navegação, pesca e safári) também permanecem nesses locais.

Dentre as principais etapas utilizadas do projeto ecoturístico, no que tange ao conhecimento técnico em arquitetura e paisagismo, podemos mencionar: a pesquisa/análise/ coleta de dados, passando pelo cruzamento desses dados, elaboração de programas funcionais e físico-espaciais (diagnóstico da paisagem, mapas temáticos e projeto técnico), até a proposta para sua implantação. Auxílios de sobrevôos, fotografias aéreas, mapas e plantas de todo o tipo de informação escrita e fotográfica contribuem para compor uma imagem mais analítica da paisagem e uma divulgação mais precisa das informações aos usuários, sobre os locais e seus atrativos a serem visitados. Convém 
lembrar que cada lugar possui suas próprias características ambientais e paisagísticas, o que resulta em propostas projetuais arquitetônicas e paisagísticas diferenciadas.

"Portanto, além dos fatores mencionados anteriormente, outros condicionantes fazem-se necessários a serem incorporados no estudo técnico, no que diz respeito ao projeto arquitetônico e paisagístico, deve seguir as seguintes fases:

1. Análise do espaço de domínio do atrativo, para o que se deve determinar: a) o raio de influência visual, que se traça tomando como centro o próprio atrativo, mas olhando para fora, e vice-versa, a partir dos pontos de acesso, a fim de eliminar qualquer artefato que se interponha nos campos visuais e determinar as partes em que se proibirá todo tipo de construção e, b) o raio de influência sonora para evitar que ruídos alheios, cheguem até os turistas e polvam o ambiente ao se sobrepor ou anular os sons da natureza;

2. Projetos dos acessos para veículos e das áreas de estacionamento em locais estratégicos, que os ocultem do raio de influência visual;

3. Projeto do empreendimento e instalações turísticas, com o mesmo critério do item anterior e a elaboração de pautas de desenho que limitem o tamanho das edificações, fixem os tipos de materiais a serem utilizados e ditem normas às quais se deverão ajustar os volumes edificados;

4. Zoneamento das áreas acessíveis, estabelecendo densidades de ocupação segundo as atividades ecoturísticas e o traçado de trilhas e circuitos de circulação." (BOULLÒN, 2002).

Além da paisagem, o projeto ecoturístico deve promover uma maior integração com o meio natural, bem como a leitura, interpretação de seus usuários, pela utilização de elementos que se agregam na mesma sob a forma de um mimetismo policrômico, por meio da estrutura física proposta: infra-estrutura, mobiliário, equipamentos e vegetação.

O quadro abaixo apresenta, de forma esquemática, a representação sistêmica dos elementos que, necessariamente, devem estar envolvidos no projeto de ecoturismo. Isso significa que, se um desses elementos não estiver engajado no processo projetual, ele pode contribuir como impacto negativo no patrimônio natural e cultural que se pretende conservar, ou seja, o projeto não estaria cumprindo com seu papel de preservação e educação ambiental.

Os arquitetos paisagistas, técnicos, empreendedores, instituições públicas e privadas envolvidas, prefeitura e população local são os responsáveis pelo projeto, funcionamento e relação entre todos os elementos. Todos devem ter participação no processo, contribuindo para a educação ambiental, o preparo técnico, a capacitação de pessoal, a criação de emprego, a manutenção e a divulgação do processo.

Em relação às estruturas físicas nas unidades de conservação, como: as edificações, as estradas, as trilhas, equipamentos e instalações, o mobiliário, as sinalizações, as torres, os locais de observação, a vegetação devem ser projetados de maneira a não 


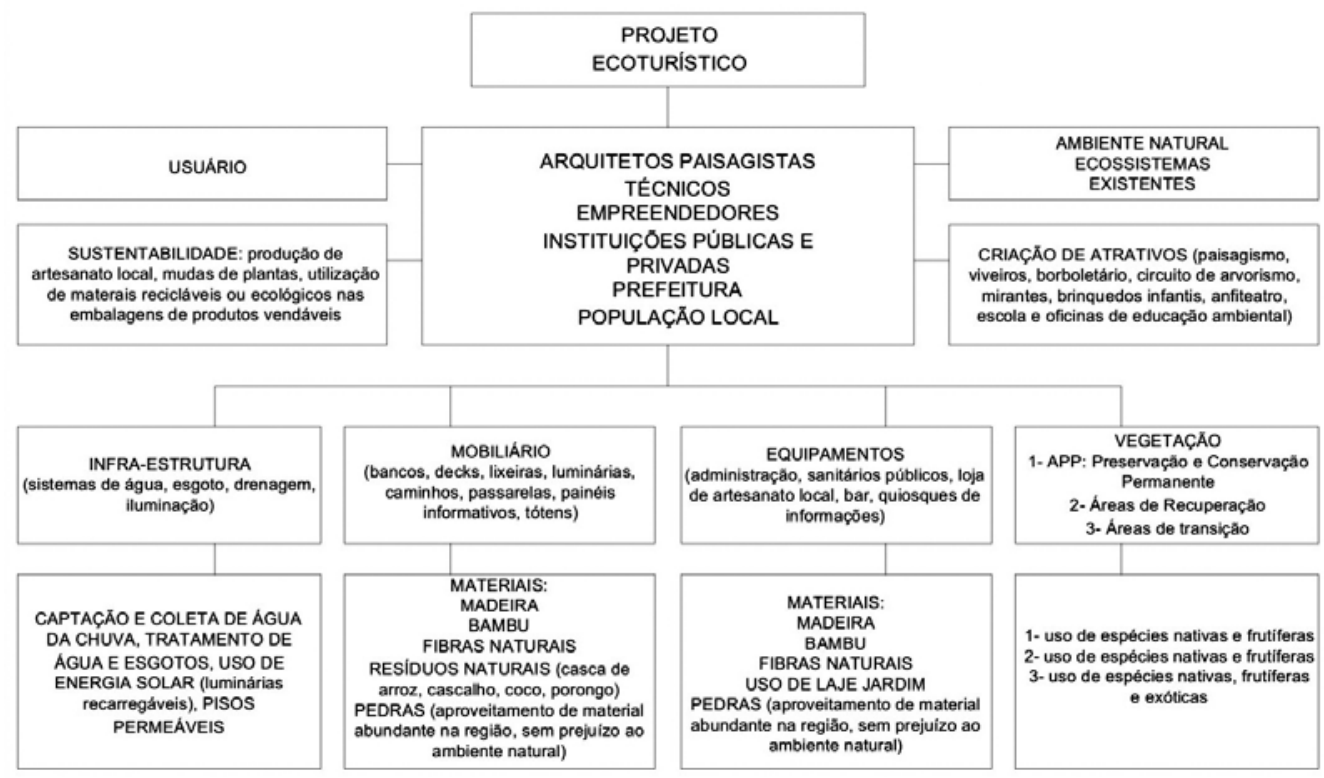

Figura 3: Quadro esquemático dos elementos envolvidos no processo projetual paisagístico do Ecoturismo Elaboração: Autores, 2009

interferir abruptamente no meio ambiente, e tornar mais rica a experiência do visitante. A criação de atrativos contribui para suprir com as expectativas do usuário para que esse desfrute do ambiente integrado, sem destruir, com responsabilidade e educação ambiental, tornando-se mais um elemento responsável pela conservação e não como um impacto ao meio.

A manutenção dos elementos naturais e ecossistemas é o foco do projeto e está estreitamente ligado aos princípios de planejamento da paisagem ecológica. Esse princípio também se aplica aos materiais e técnicas alternativas empregados no projeto de paisagismo e arquitetura, no qual a responsabilidade, sensibilidade e criatividade do projetista é ainda maior, devendo permitir a integridade, a flexibilidade, a modulação, a montagem, a desmontagem e a relocação dos elementos sem impactos e sem deixar resíduos no ambiente natural.

\section{Estudos de caso: Chattahoochee River - Natinal Recreation Área - Atlanta - GA - USA e Okefenokee National Wildlife Refuge - Folkston - GA - USA}

O parque Chattahoochee River - Natinal Recreation Área, conformado por um dos rios mais importantes dessa porção sul do estado da Geórgia por meio da arquitetura paisagística (análise, planejamento e projeto), recompôs suas áreas degradadas pelas ações antrópicas, pela reconstituição ecogenética, promovendo a recuperação ambiental e conservação das porções significativas do patrimônio natural pela conformação de um parque linear ao rio. Os corredores ecológicos (azuis: pela água, e verdes: pela vegetação) presentes interligam suas unidades menores (Island Ford Vickery Creek), 


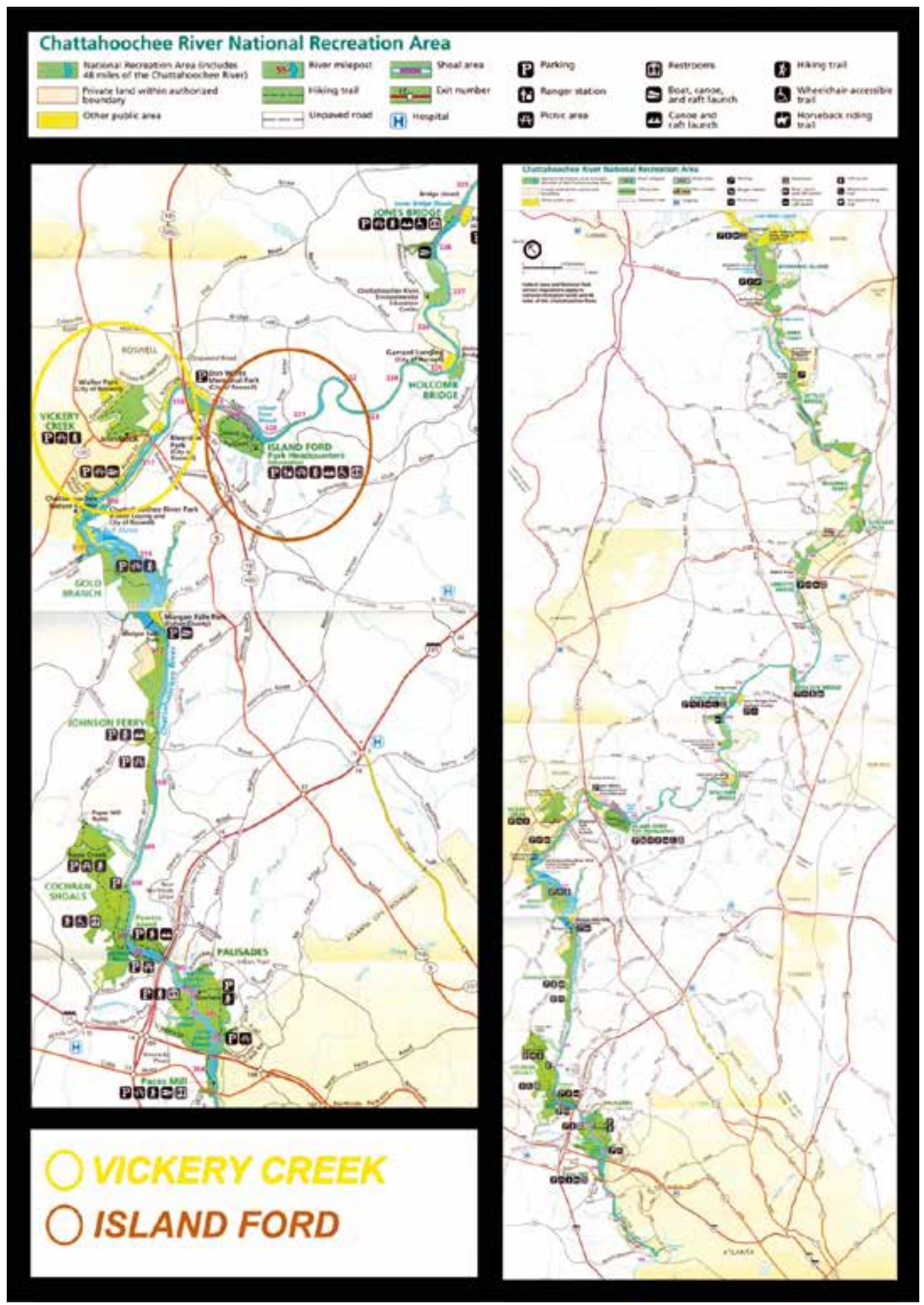

Figura 4: Mapa temático global/parcial de localização das unidades de parques: Vickery Creek e Island Ford Chattahoochee river - National recreation área - Atlanta - GA - USA Fonte: Acervo pessoal Pippi, 2009 


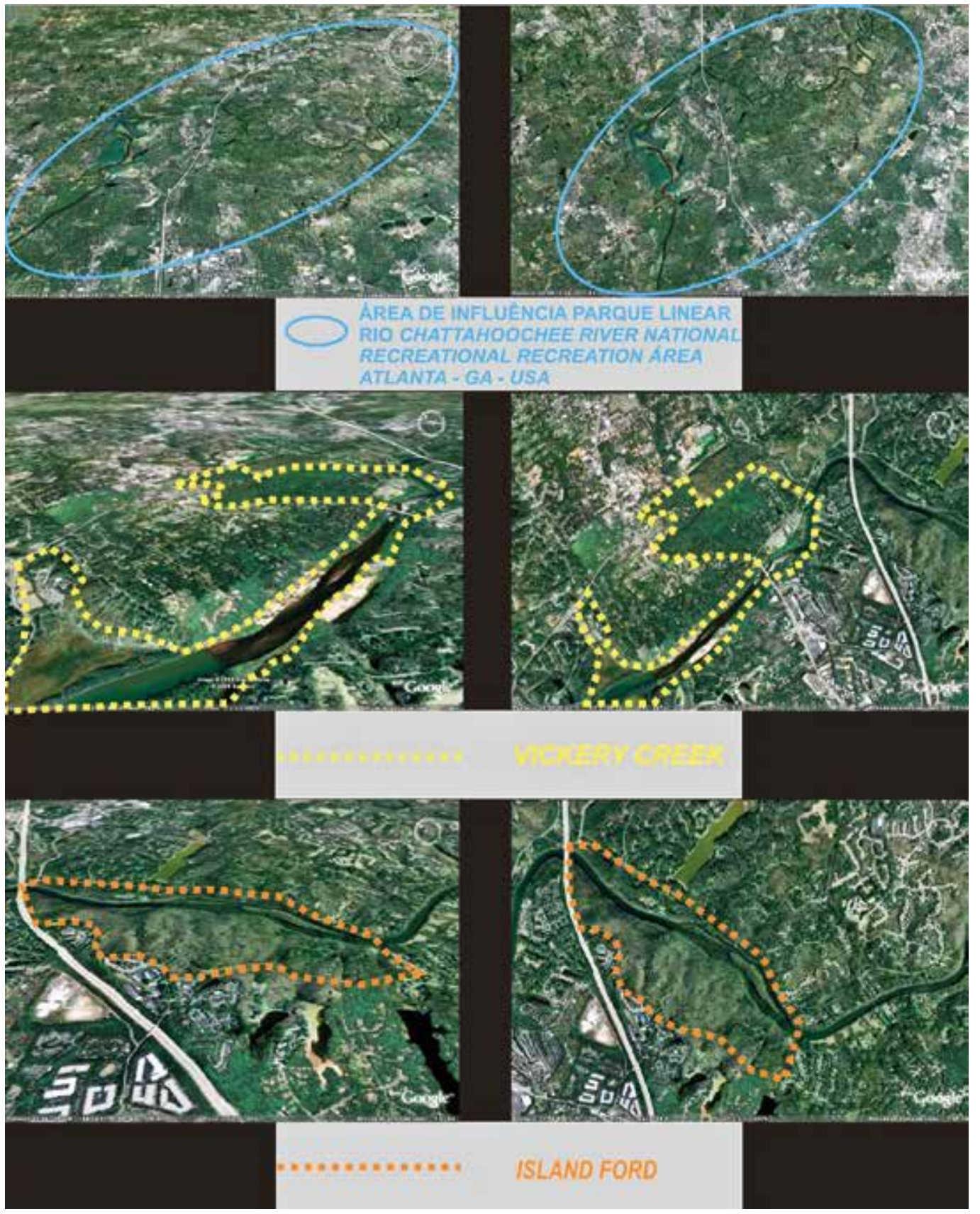

Figura 5: Localização área dos parques: Vickery Creek e Island Ford Chattahoochee river - National recreation área - Atlanta - GA - USA

Elaboração: Pippi, a partir de GOOGLE EARTH, 2009 

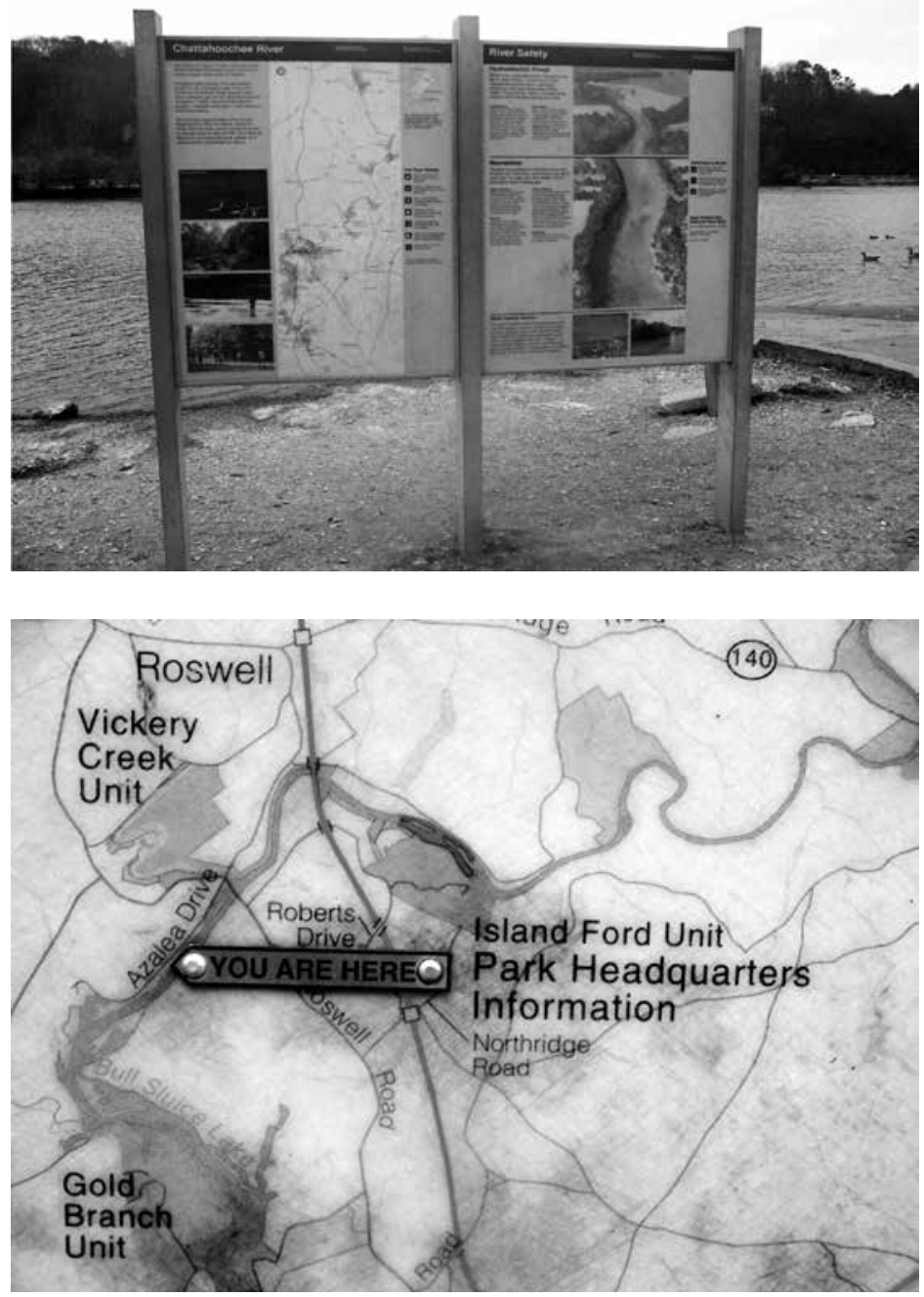

Figura 6: Painel informativo com mapa temático global/parcial de localização da unidade: Vickery Creek

Chattahoochee river - National Recreation Área: Vickery Creek Atlanta - GA - USA

Fonte: Acervo pessoal Pippi, 2006
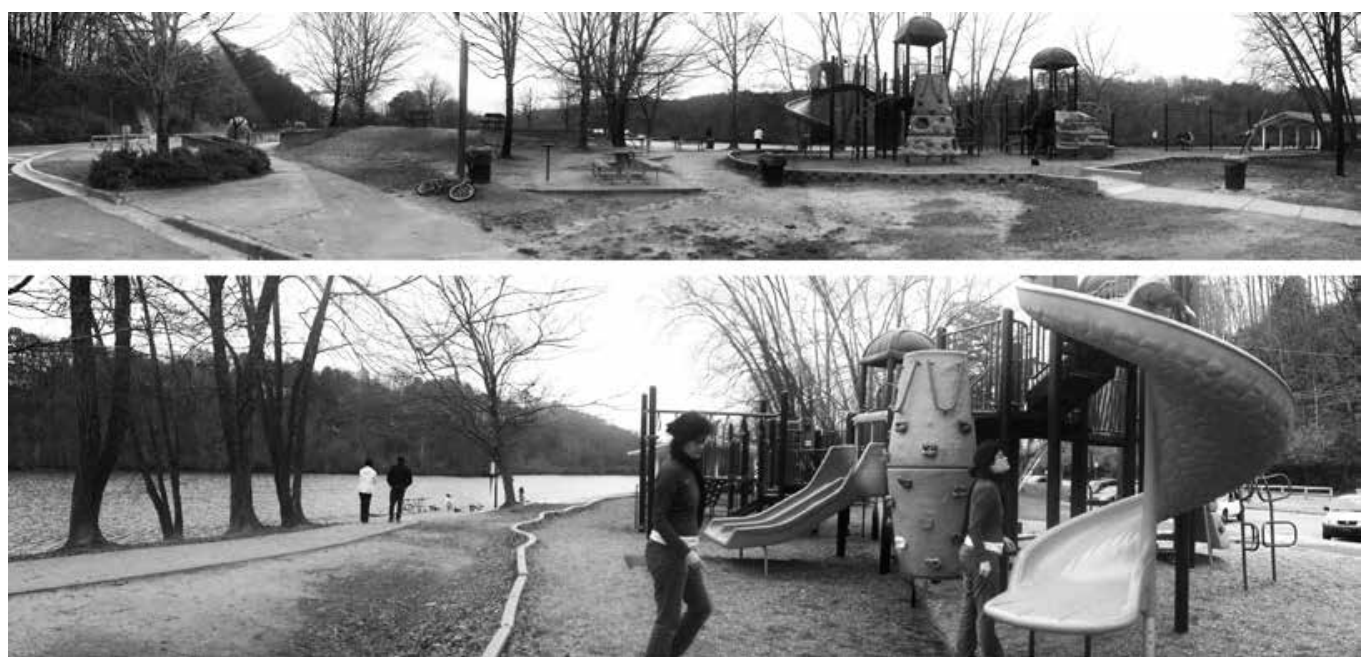

Figura 7: Área de recreação e contemplação da paisagem natural. Peatonal/ciclovia e playground linear ao Chattahoochee river - National recreation área: Vickery Creek - Atlanta - GA - USA Fonte: Acervo pessoal Pippi, 2006 

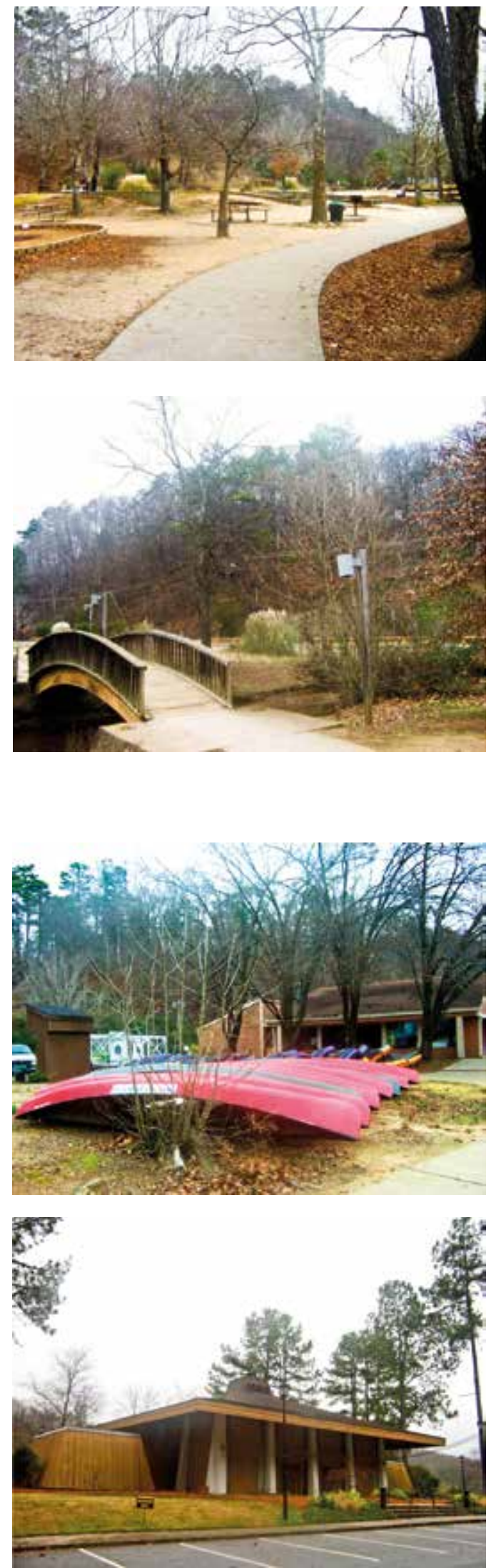

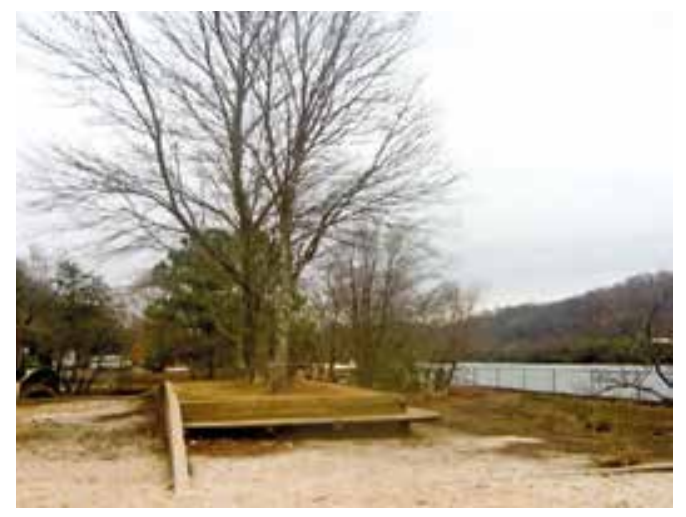

Figuras 8, 9 e 10: Peatonal sinuosa, recanto de estar para contemplação da paisagem (floreira/banco dormentes) e ponte de madeira. Chattahoochee river - National recreation área: Vickery Creek - Atlanta GA - USA

Fonte: Acervo pessoal Pippi, 2006

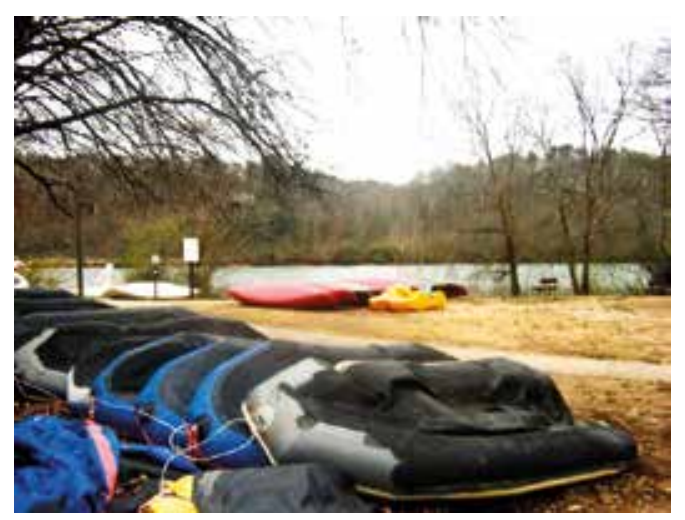

Figuras 11, 12 e 13: Ancoradouro (botes, canoas e pedalinhos) e edificação (administração/museu/ auditório). Chattahoochee river - National recreation área: Vickery Creek - Atlanta - GA - USA Fonte: Acervo pessoal Pippi, 2006 


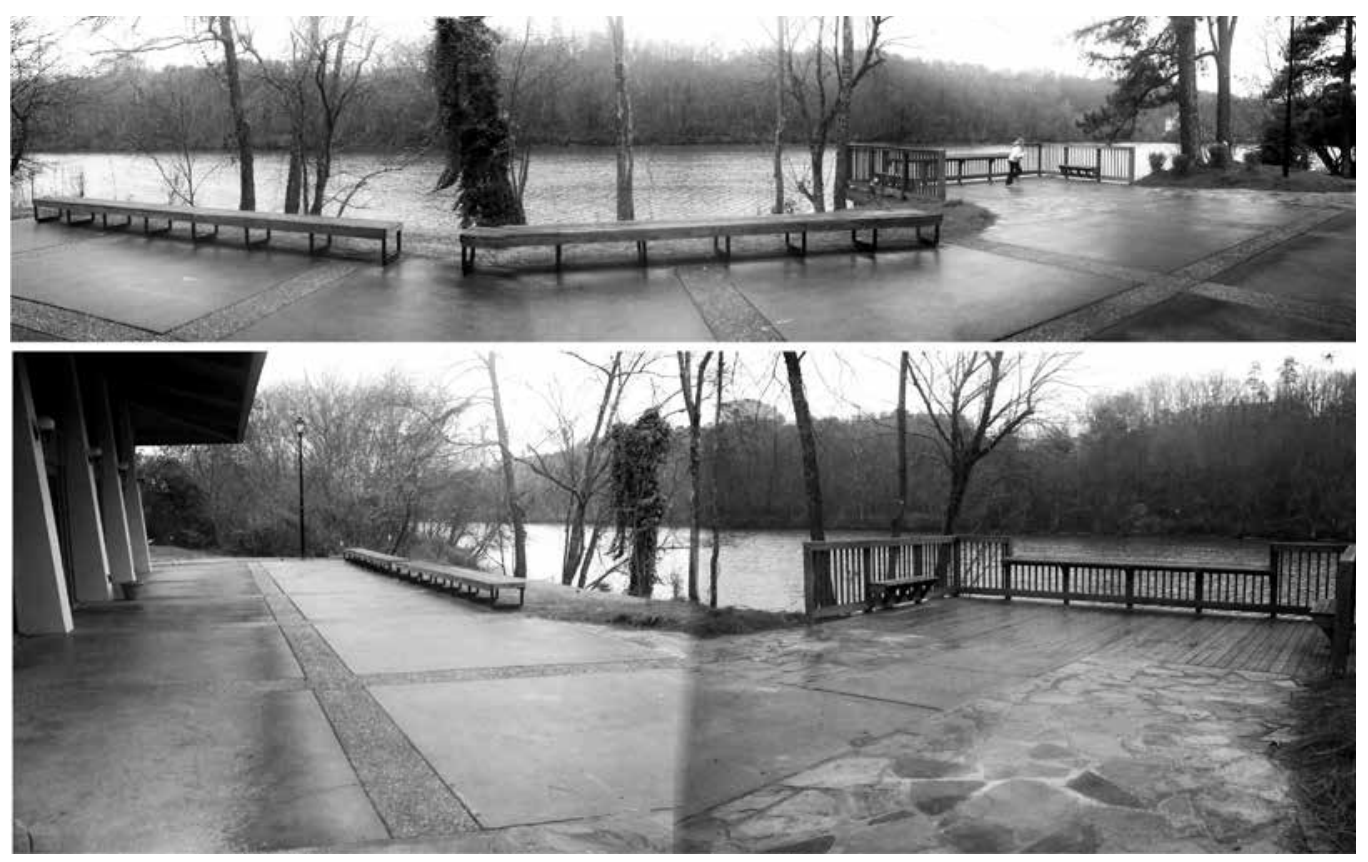

Figuras 14 e 15: Recursos naturais e recantos de contemplação da paisagem natural (deck, mobiliário) dos materiais presentes no mobiliário e revestimentos de piso integrados à paisagem natural pela policromia).

Chattahoochee river - National recreation área: Vickery Creek - Atlanta - GA - USA

Fonte: Acervo pessoal Pippi, 2006

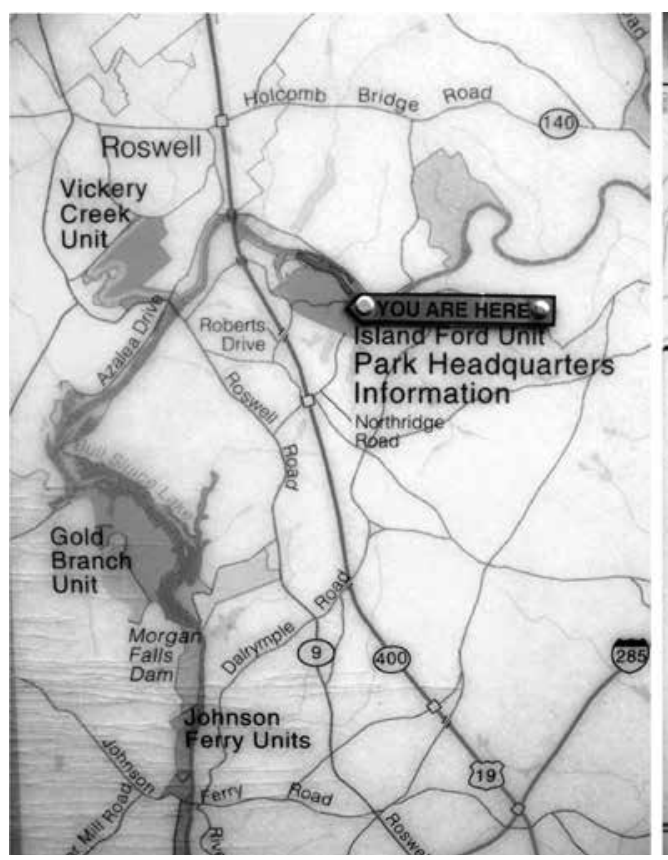

\section{Island Ford}

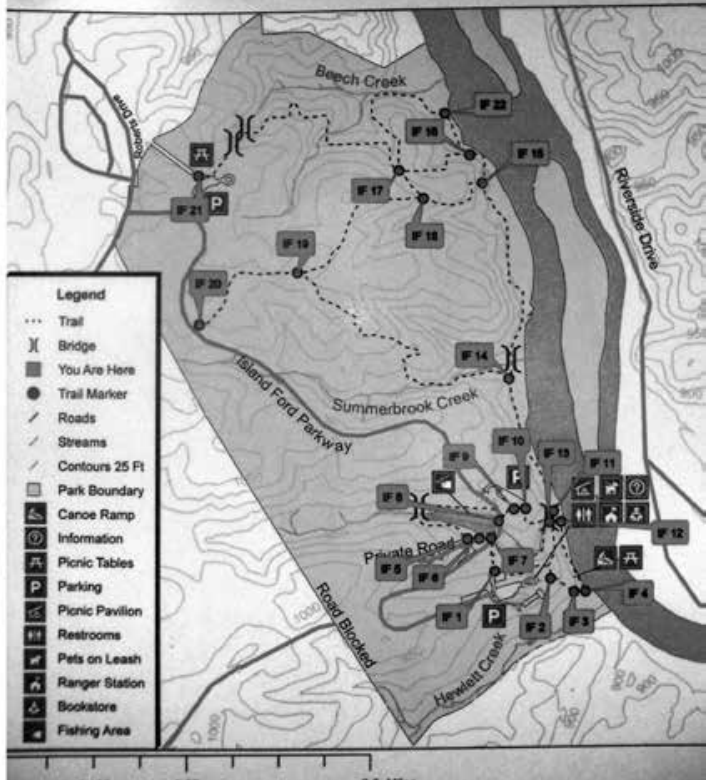

Figura 16: Painel informativo com mapa parcial de localização da unidade: Island Ford - Mapa temático. Legenda dos ambientes naturais e construídos. Chattahoochee river - National recreation área: Island Ford Atlanta - GA - USA

Fonte: Acervo pessoal Pippi, 2006 


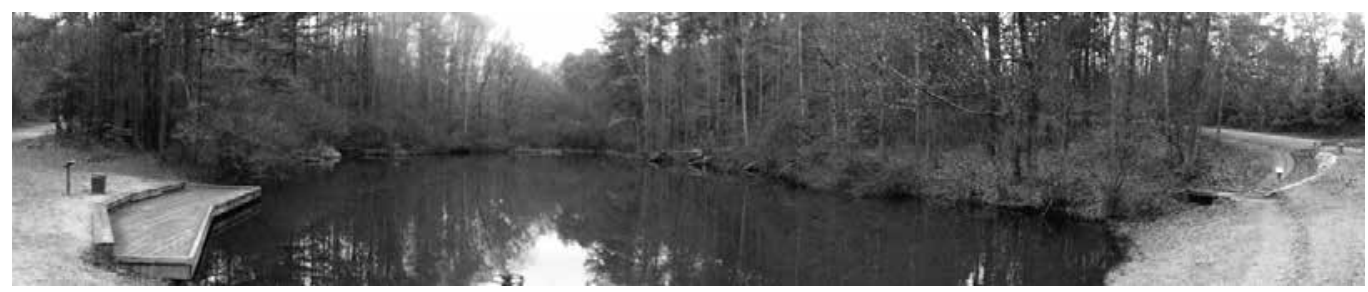

Figura 17: Recursos naturais (lago e vegetação) e recanto de contemplação da paisagem natural (deck madeira). Chattahoochee river - National recreation área: Island Ford - Atlanta - GA - USA

Fonte: Acervo pessoal Pippi, 2006
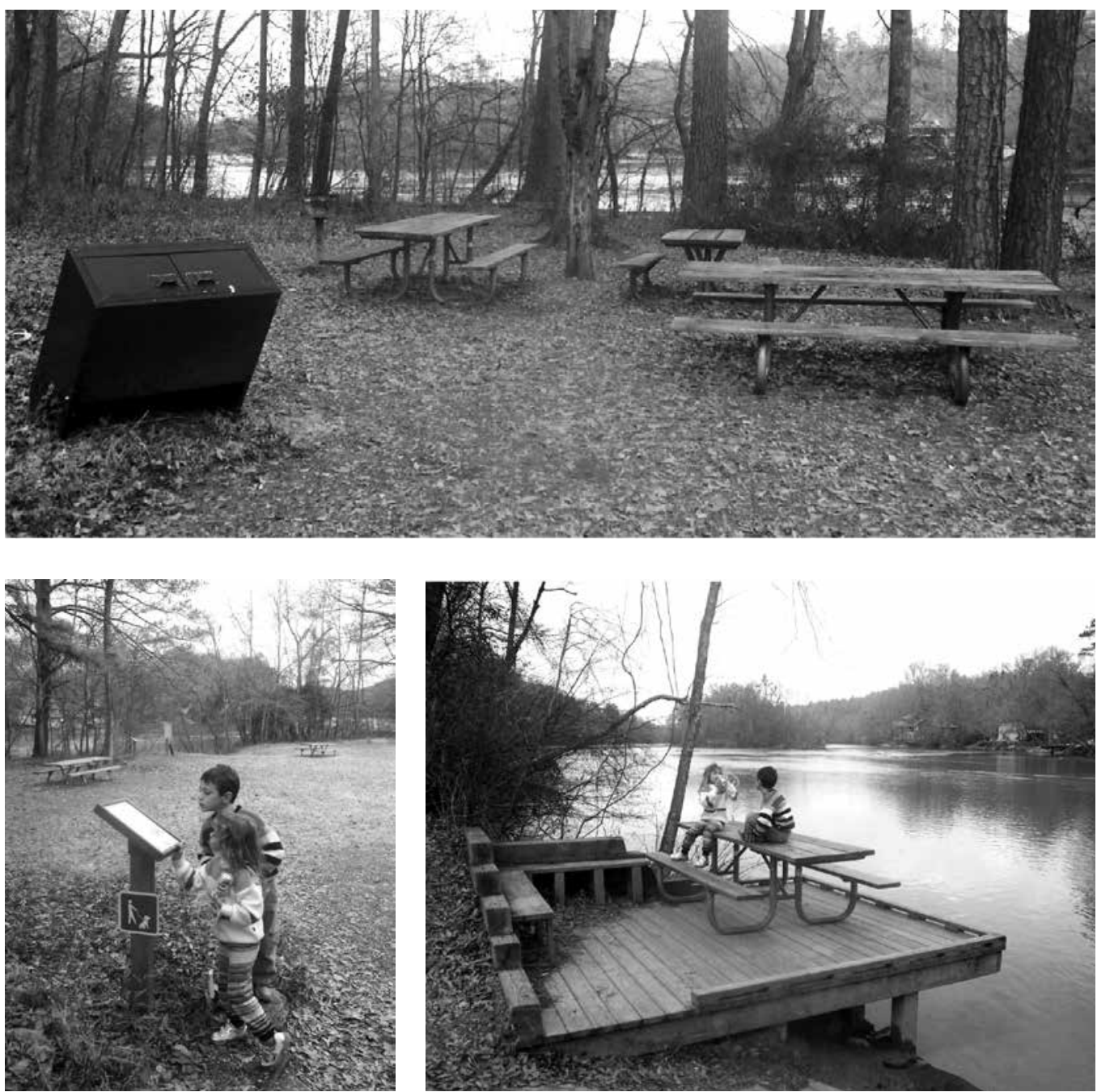

Figuras 18, 19 e 20: Área de piquenique: mobiliário (mesas e lixeiras), recantos planejados na paisagística para contemplação da paisagem natural: estar (deck, mesa e banco) e infra-estrutura de apoio: (placa informativa). Chattahoochee river - National recreation área: Island Ford - Atlanta - GA - USA

Fonte: Acervo pessoal Pippi, 2006 

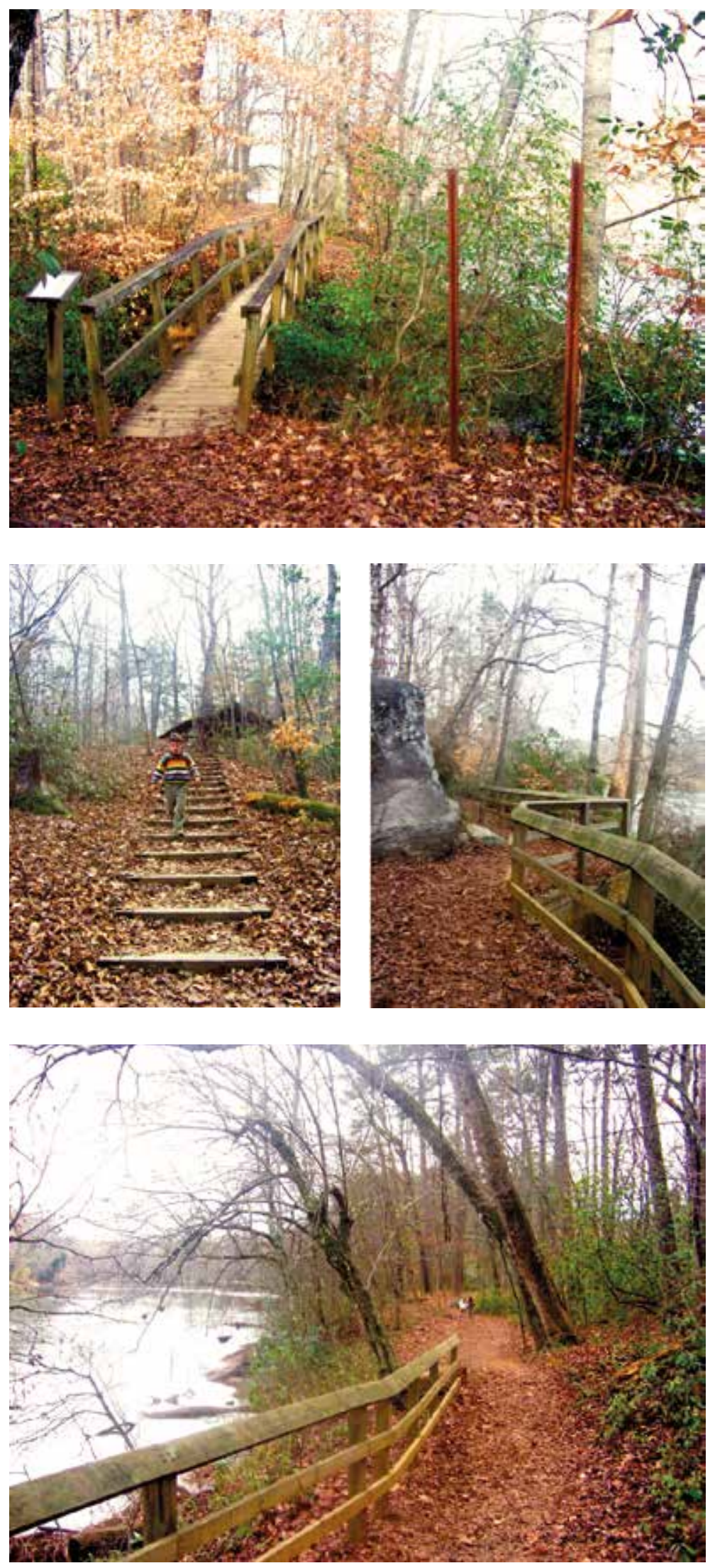

Figura 21: Área do percurso das trilhas: infra-estrutura de apoio (pontes, escadas de dormentes, guardacorpo de madeira e placa Informativa). Chattahoochee river - National recreation área: Island Ford - Atlanta GA - USA

Fonte: Acervo pessoal Pippi, 2006 

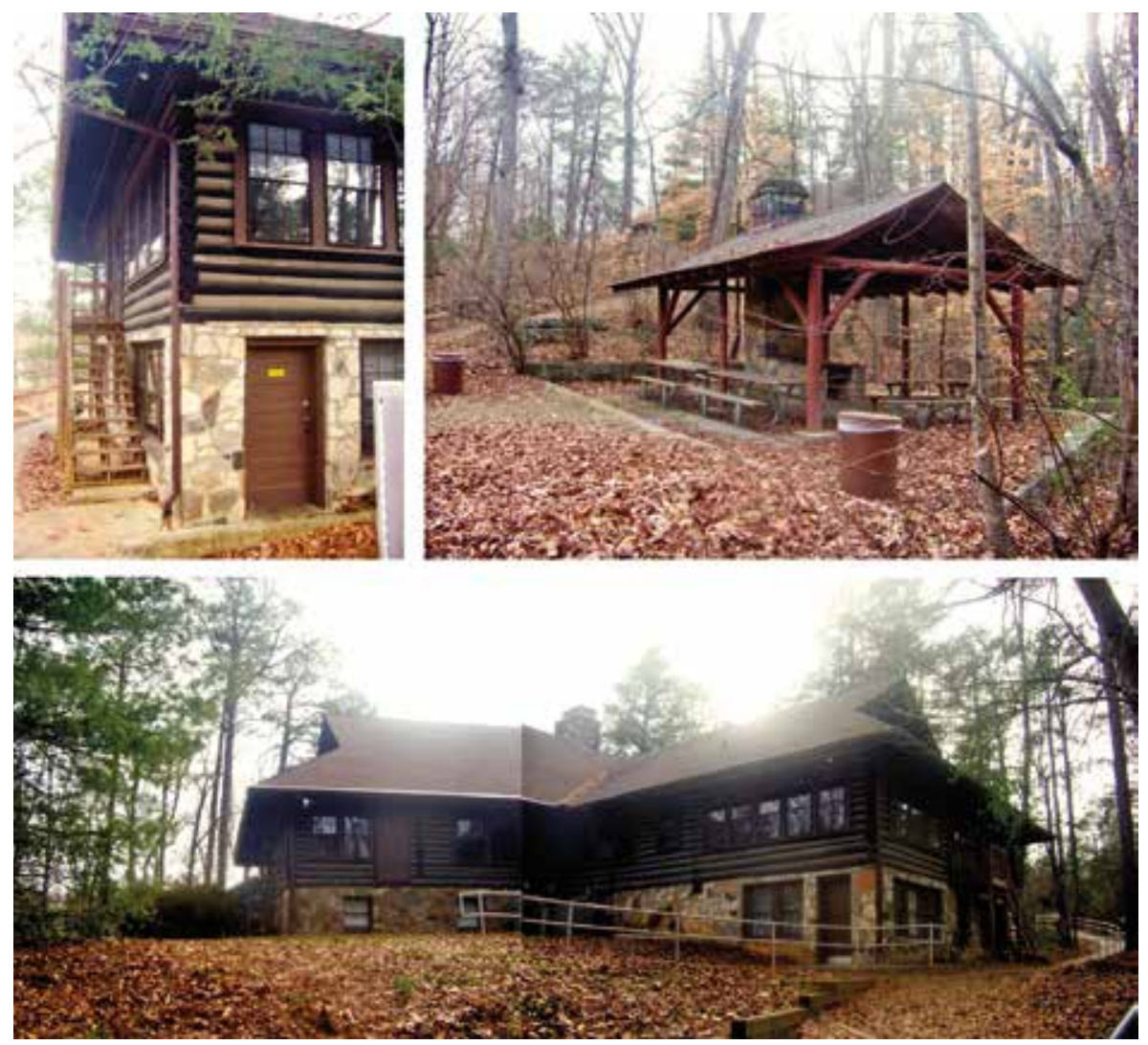

Figura 22: Equipamentos do parque: sede administrativa e ambiente da churrasqueira: infra-estrutura e materiais locais. Integração à paisagem pela policromia dos materiais construídos. Chattahoochee river - National recreation área: Island Ford - Atlanta - GA - USA

Fonte: Acervo pessoal Pippi, 2006

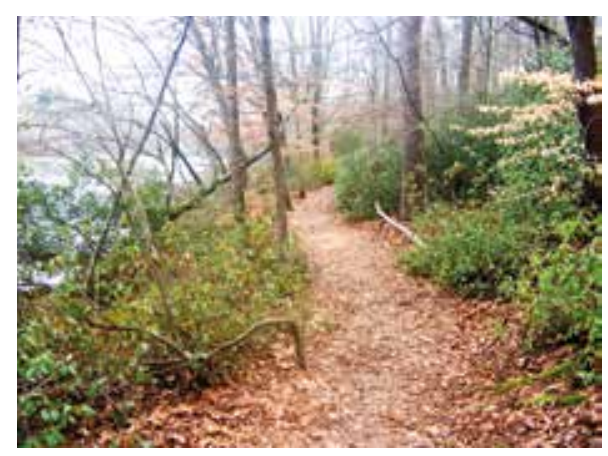

Figura 23: Área do percurso das trilhas (revestimento natural e recursos naturais) para contemplação da paisagem fechada. Chattahoochee river - National recreation área: Island Ford - Atlanta - GA - USA

Fonte: Acervo pessoal Pippi, 2006

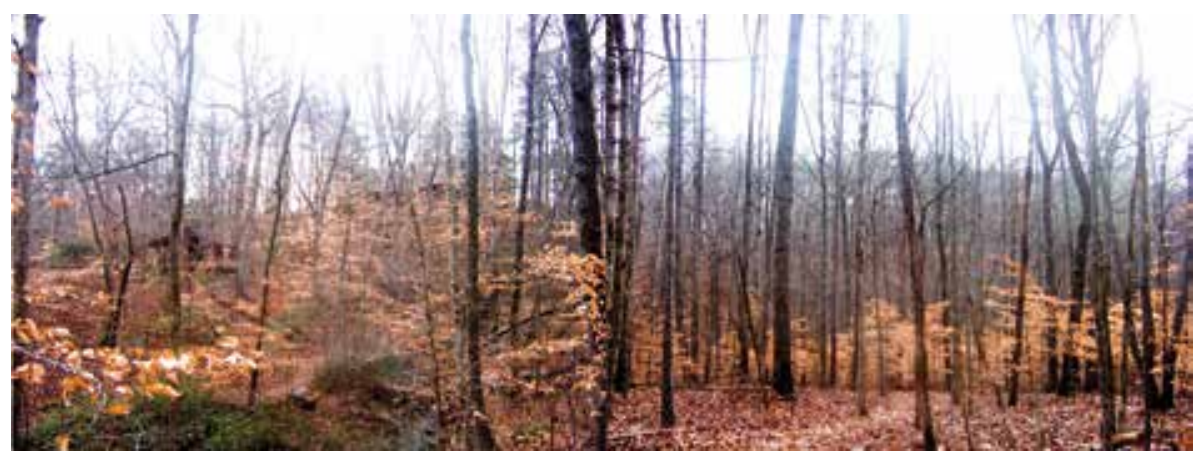



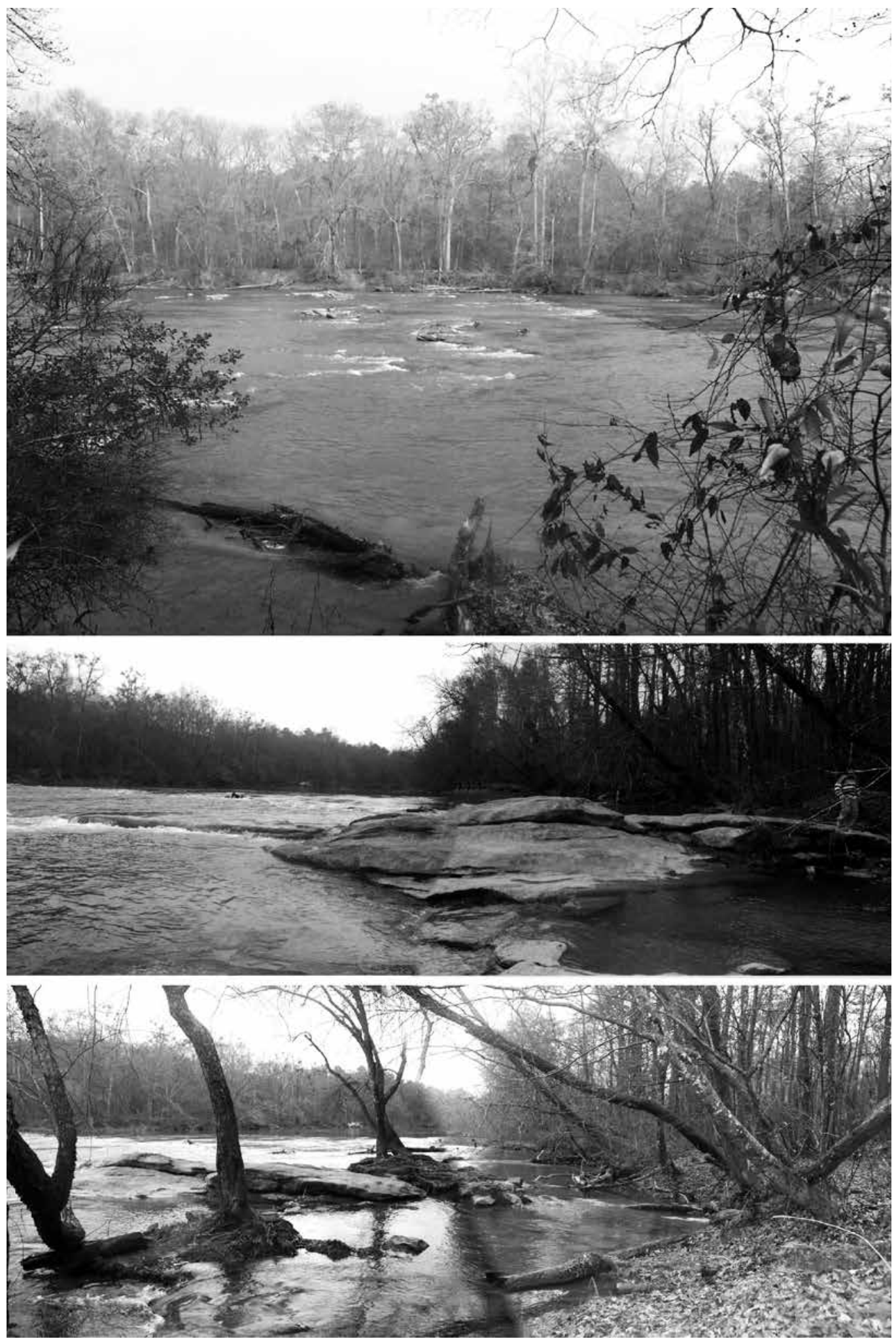

Figura 24: Pontos planejados para a contemplação da paisagem aberta. Chattahoochee river - National recreation área: Island Ford - Atlanta - GA - USA

Fonte: Acervo pessoal Pippi, 2006 

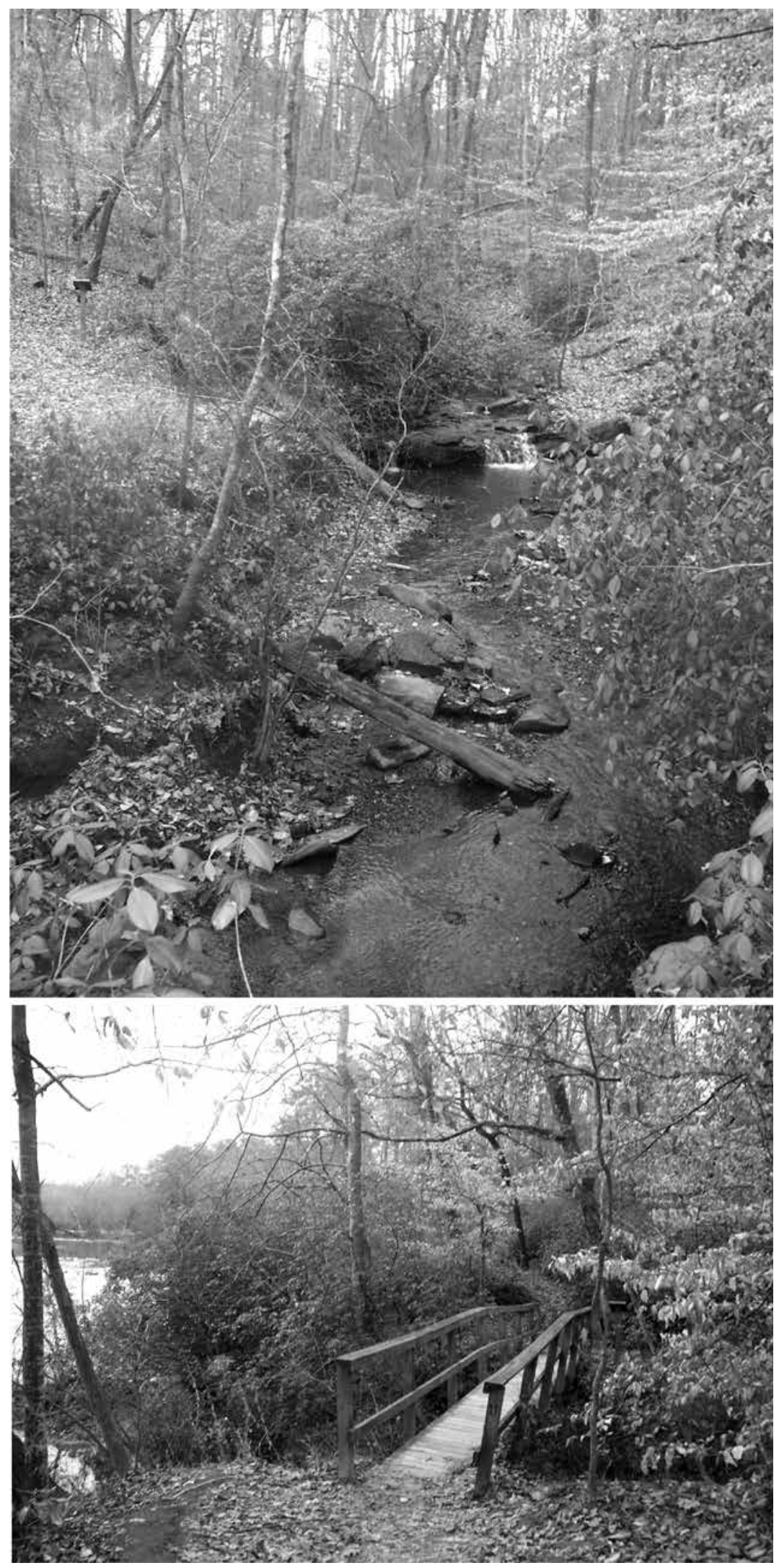

Figura 25: Área de preservação permanente: vegetação ciliar e riacho não-polvído; ponte travessia sobre ponto de encontro riacho e rio. Chattahoochee river - National recreation área: Island Ford Atlanta - GA - USA Fonte: Acervo pessoal Pippi, 2006 


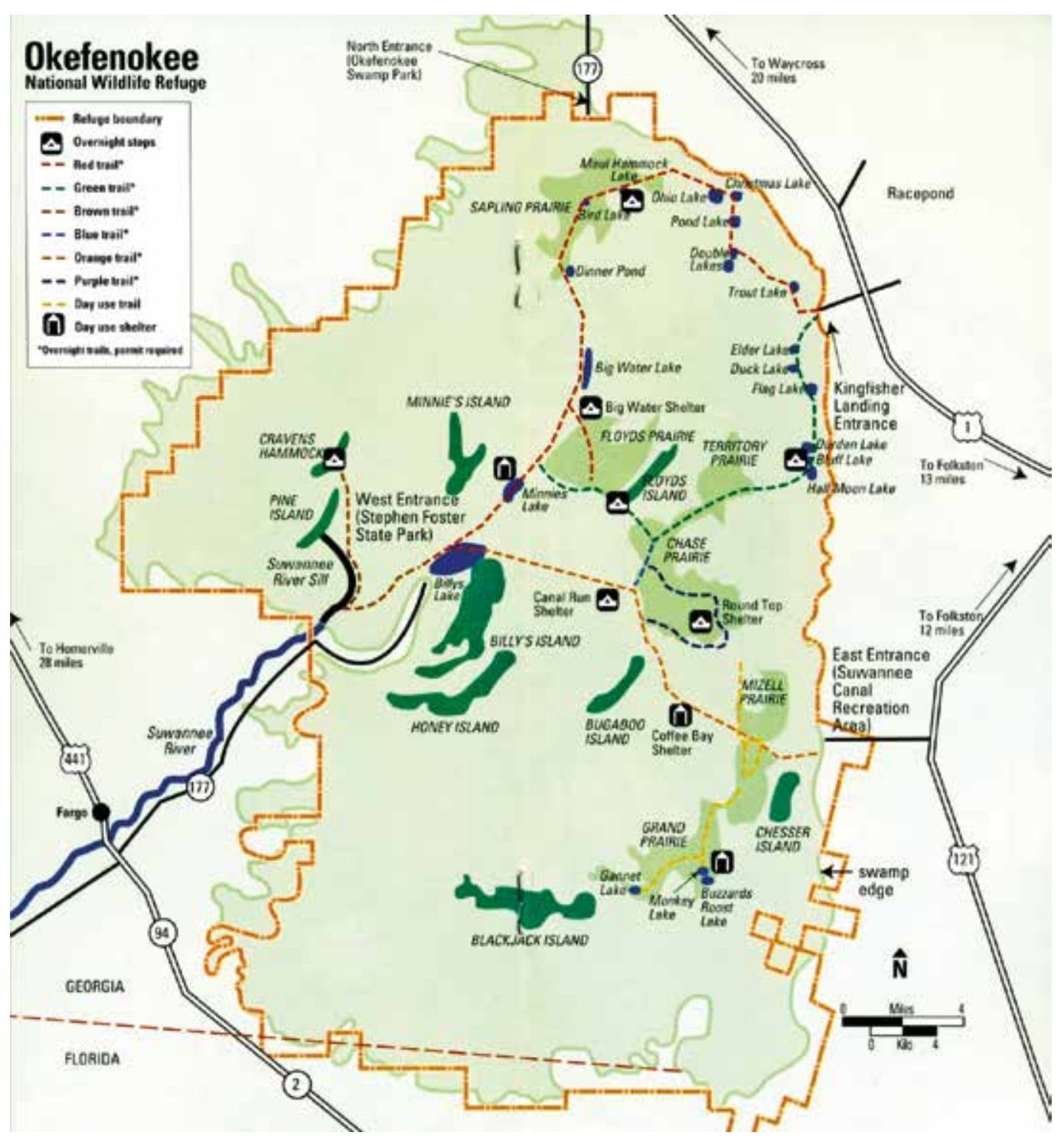

Figura 26: Mapa temático de localização do parque: Okefenokee National Wildlife Refuge - Folkston - GA - USA Fonte: Acervo pessoal Pippi, 2006 

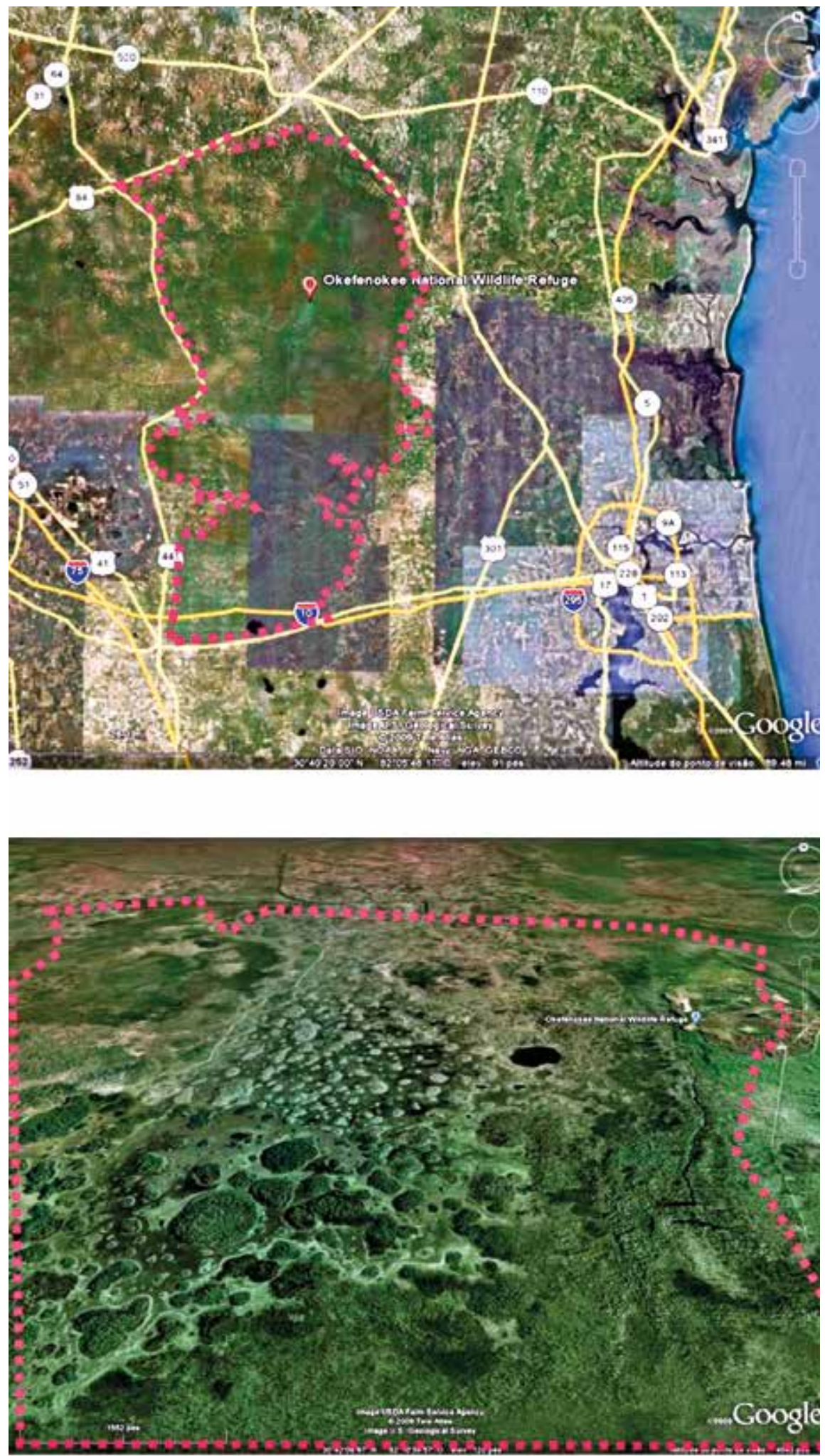

Figura 27:

Localização

da área

do parque

Okefenokee

National

Wildlife Refuge

- Folkston -

GA - USA

Crédito: Pippi,

elaborado

a partir de

GOOGLE

EARTH, 2009

Área Influência do Parque

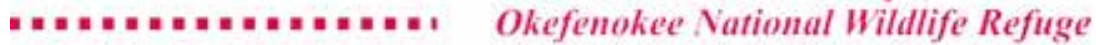

Folkston-GA-USA 

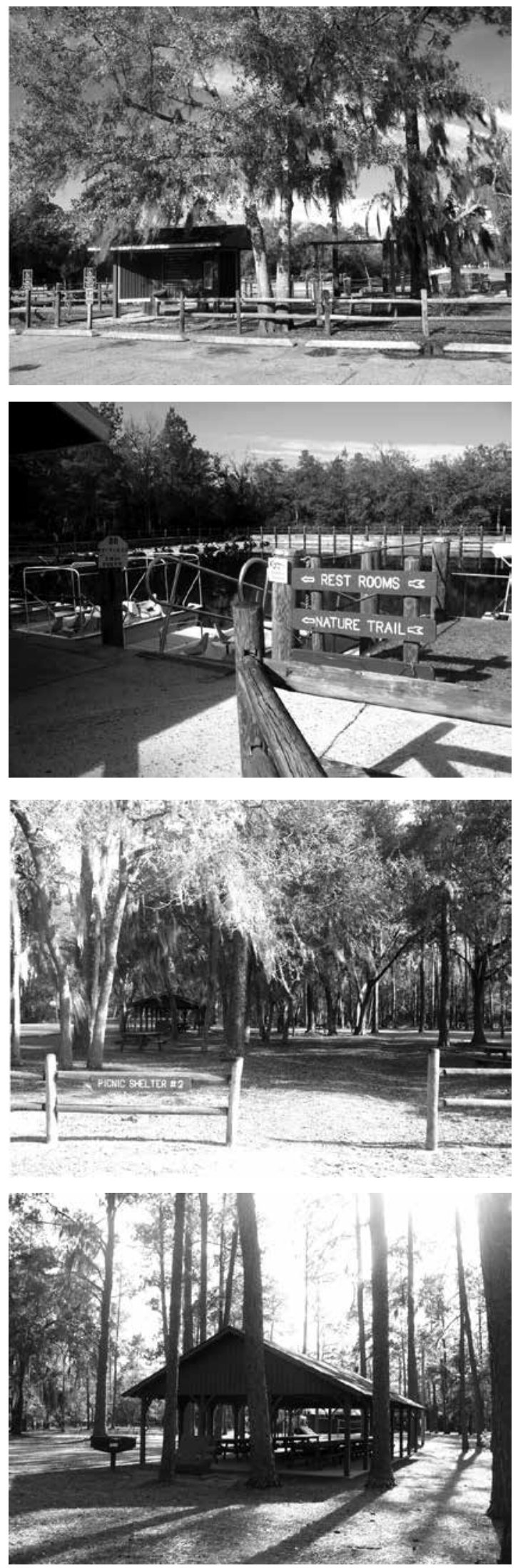

Figura 28: Área administrativa e recursos naturais: Rio Chattahoochee/Mangue. Infra-estrutura de apoio (churrasqueira, painéis informativos, ancoradouro, rampas, guarda-corpo, cercas, placa informativa). Okefenokee National Wildlife Refuge - Folkston GA - USA

Fonte: Acervo pessoal Pippi, 2006 

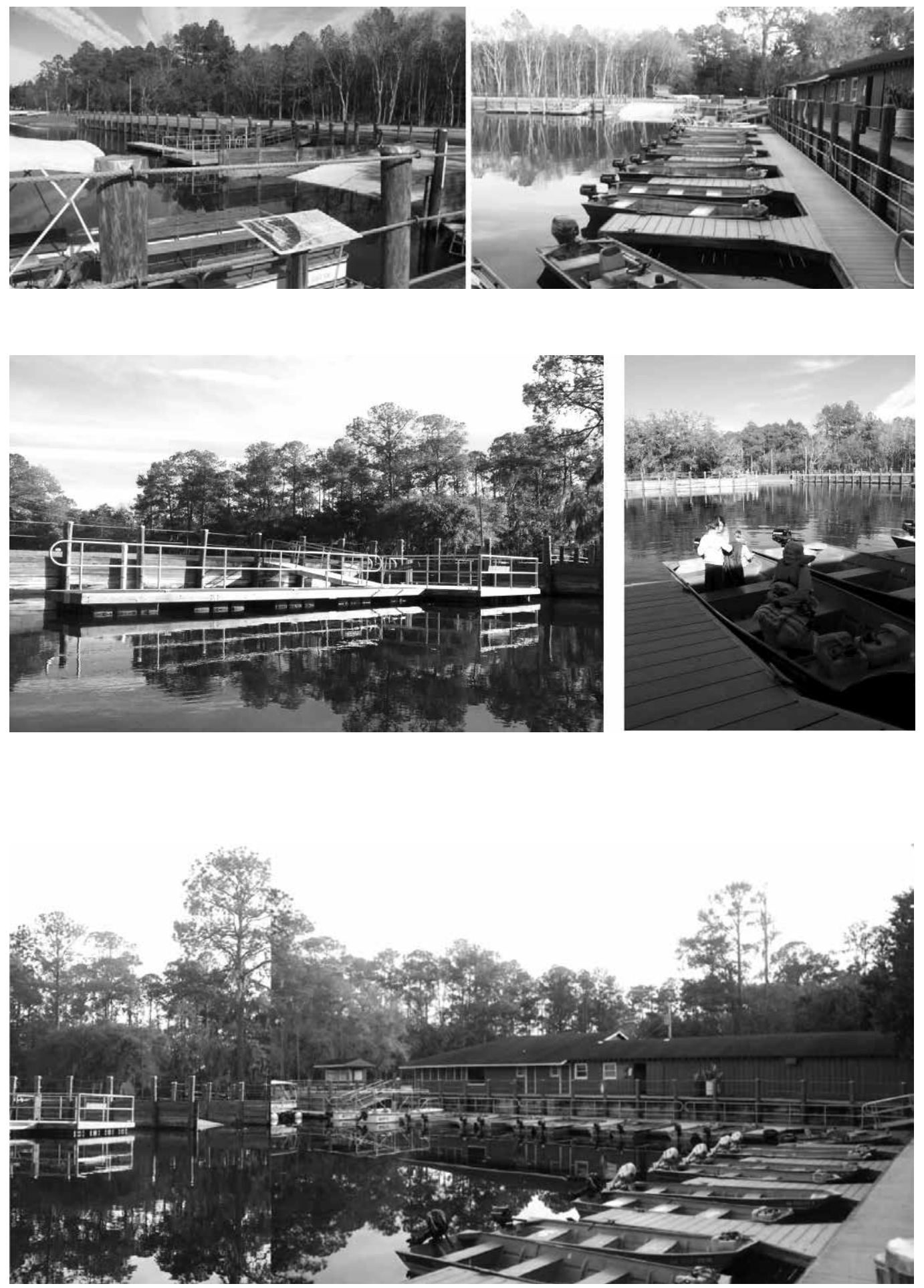

Figura 29: Infra-estrutura de apoio (ancoradouro: barcos, botes e canoas) .

Okefenokee National Wildlife Refuge - Folkston - GA - USA

Fonte: Acervo pessoal Pippi, 2006 

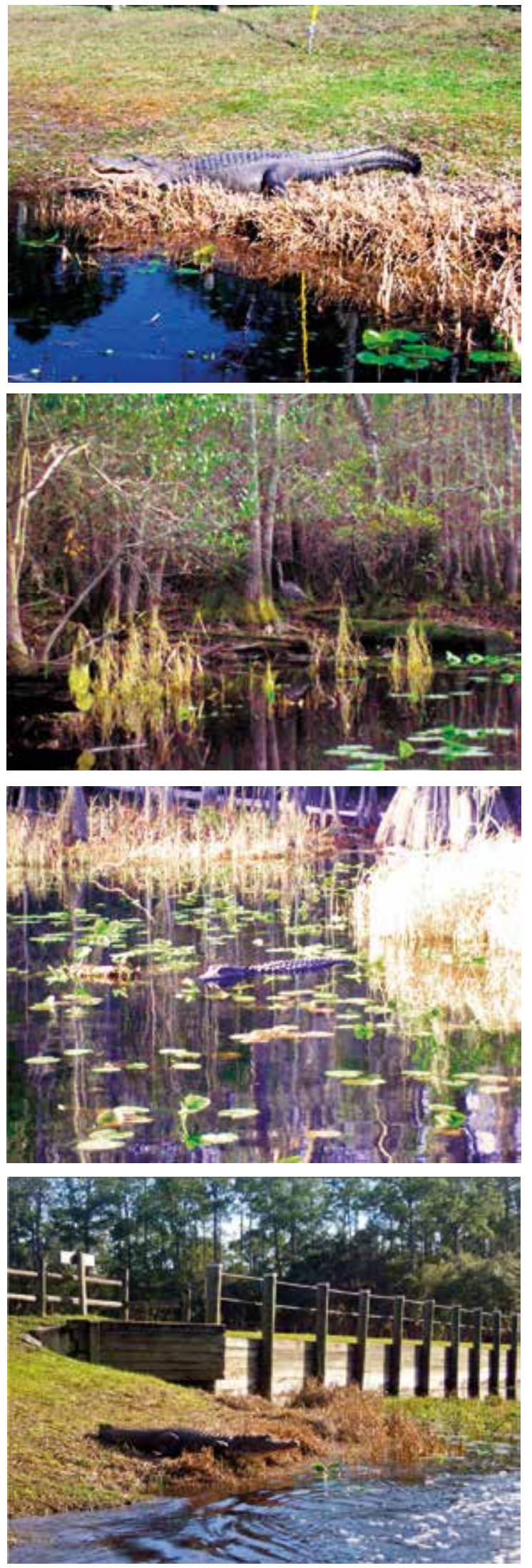

Figura 30: Ave-fauna e fauna local: crocodilo. Placa informativa de percurso corredor ecológico azul. Okefenokee National Wildlife Refuge - Folkston - GA - USA Fonte: Acervo pessoal Pippi, 2006 

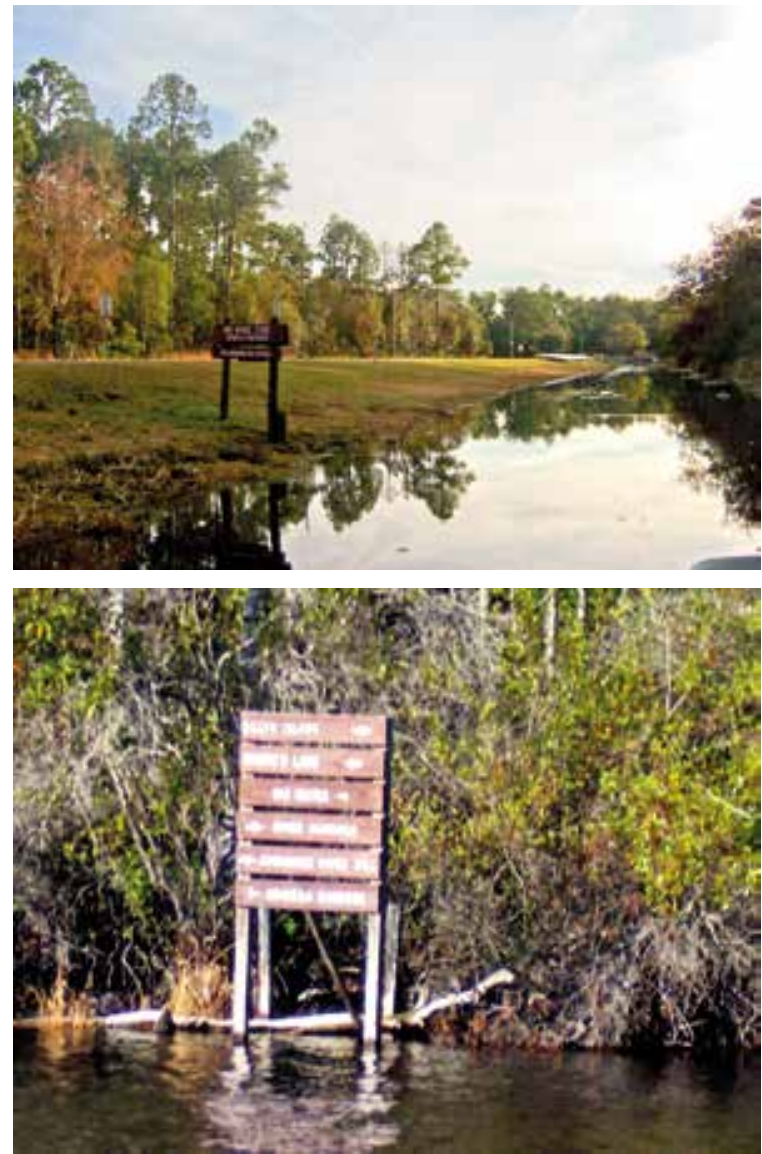

Figura 31: Placa de sinalização (local proibido para nadar), placa de informação Recantos e placa informativa de percurso Corredor Ecológico Azul.

Okefenokee National Wildlife Refuge - Folkston - GA - USA Fonte: Acervo pessoal Pippi, 2006

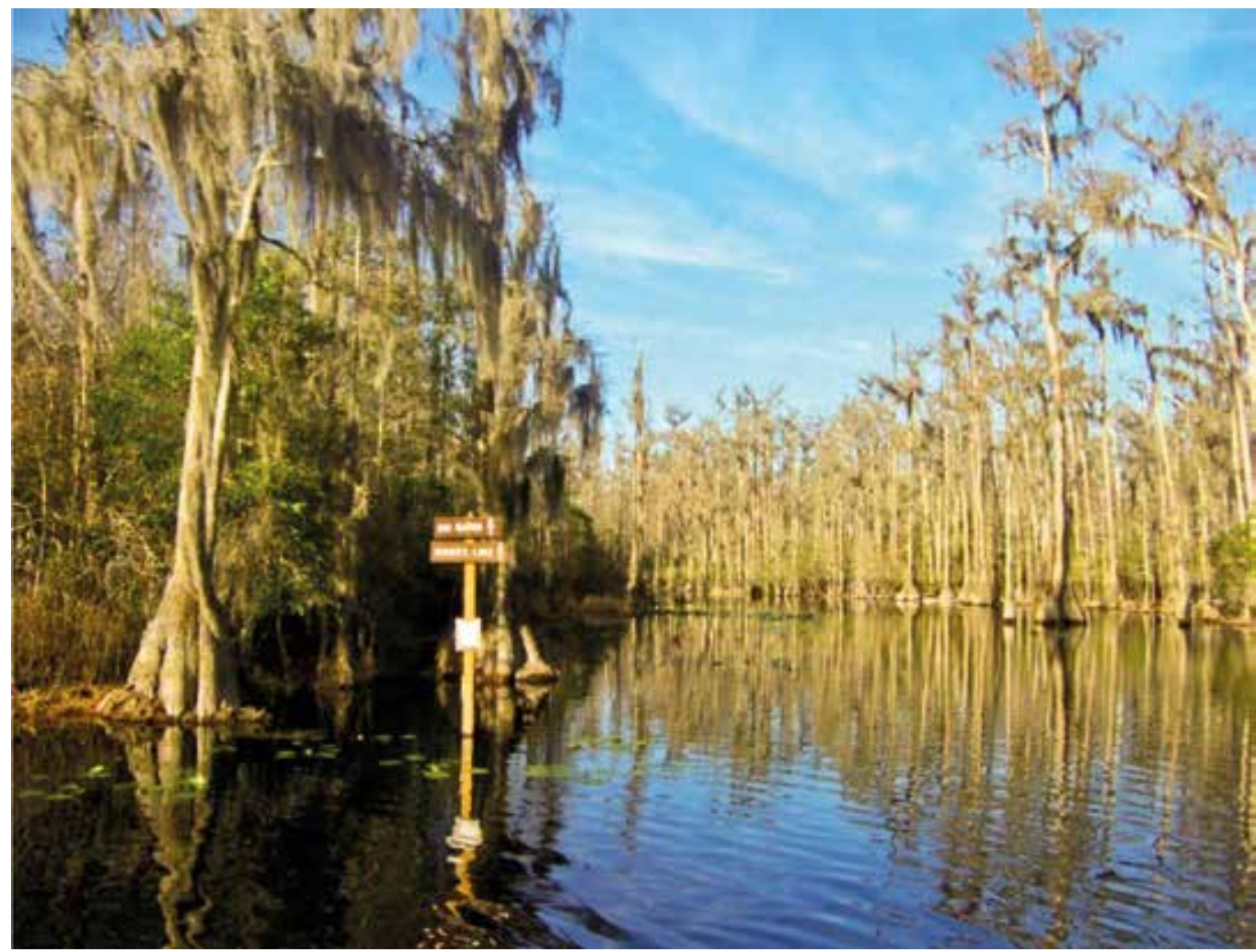



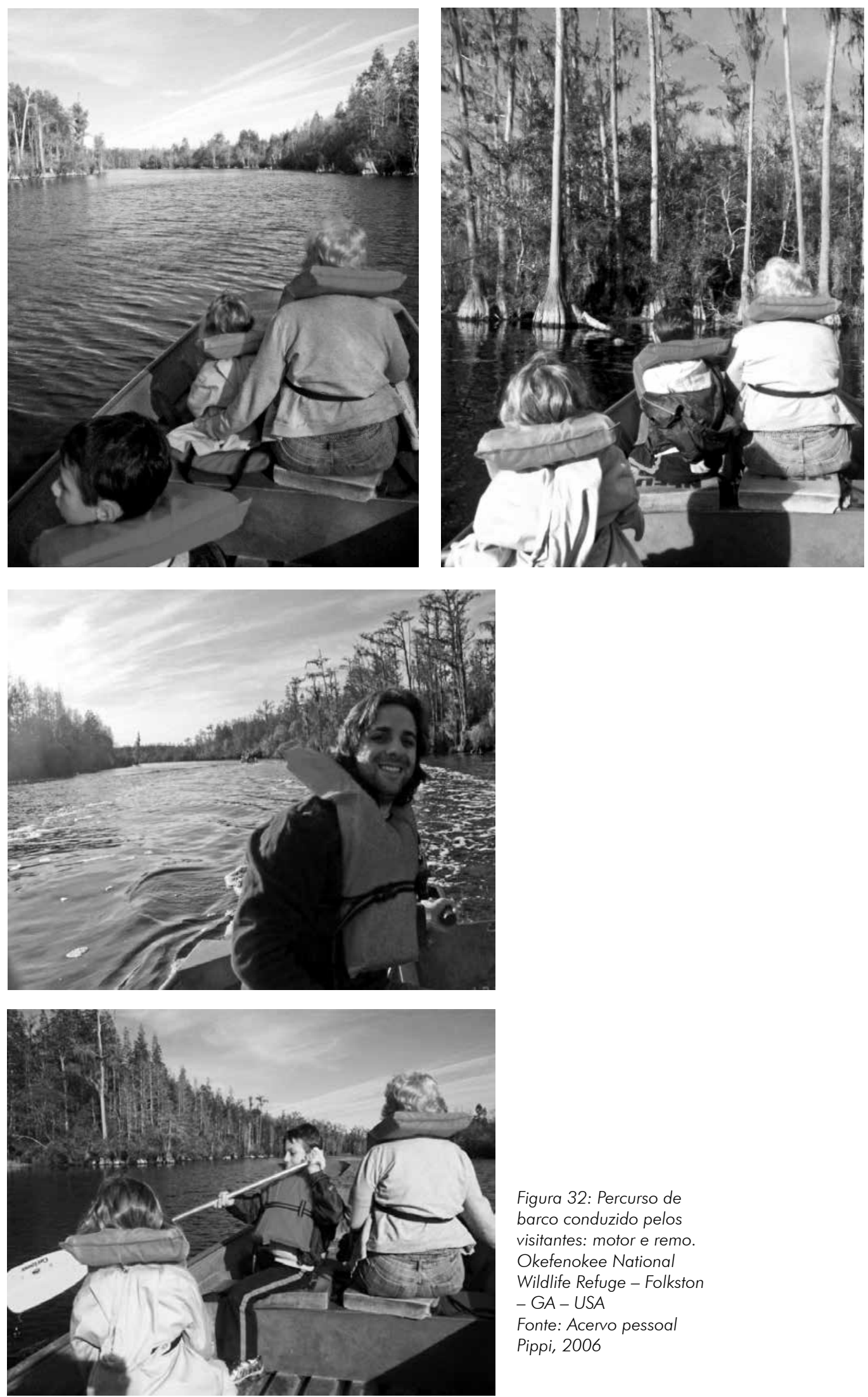

Figura 32: Percurso de barco conduzido pelos visitantes: motor e remo. Okefenokee National Wildlife Refuge - Folkston - GA - USA Fonte: Acervo pessoal Pippi, 2006 

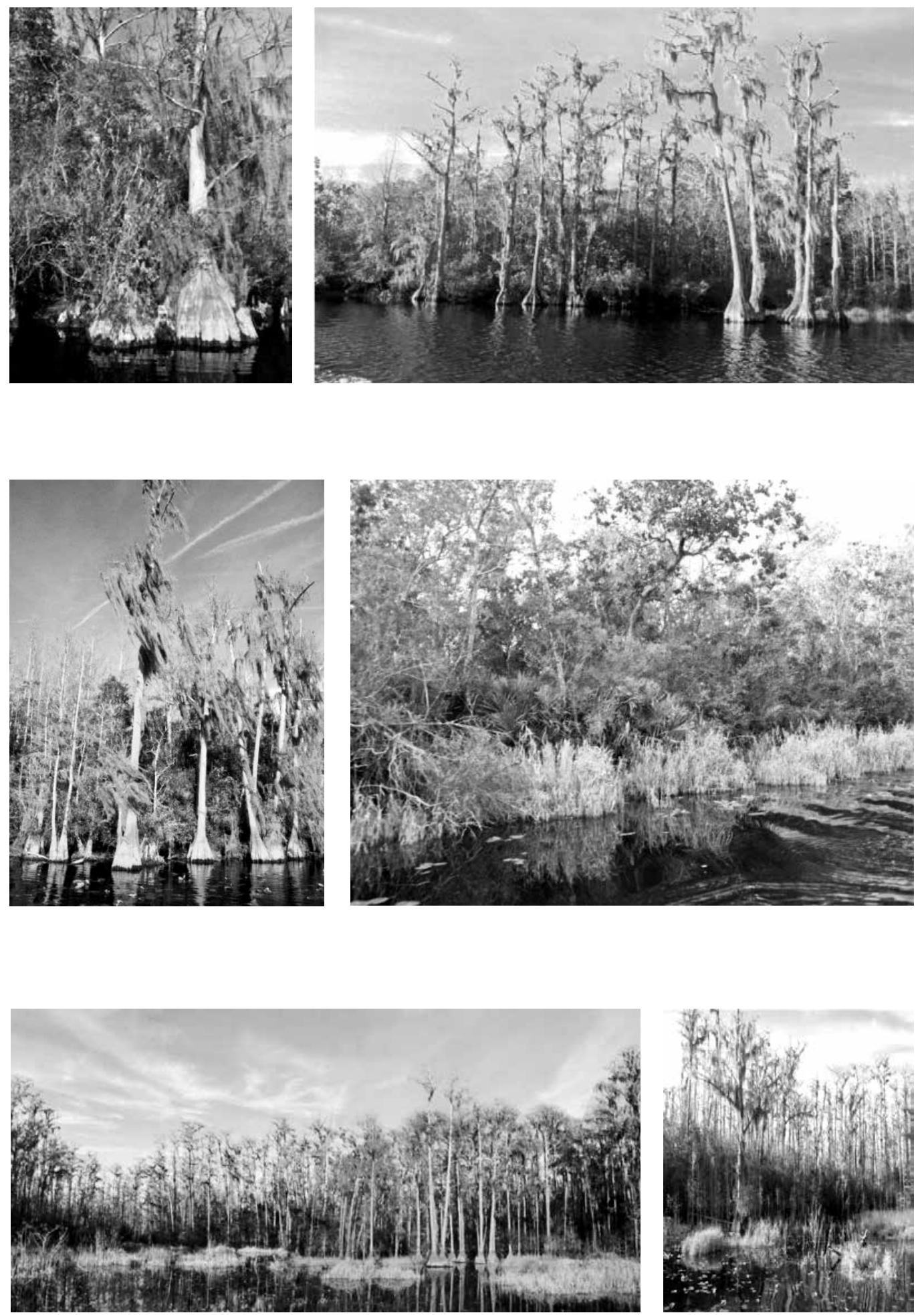

Figura 33: Qualidade cênica da paisagem, visuais, interpretação e leitura dos elementos da paisagem natural. Okefenokee National Wildlife Refuge - Folkston - GA - USA

Fonte: Acervo pessoal Pippi, 2006 

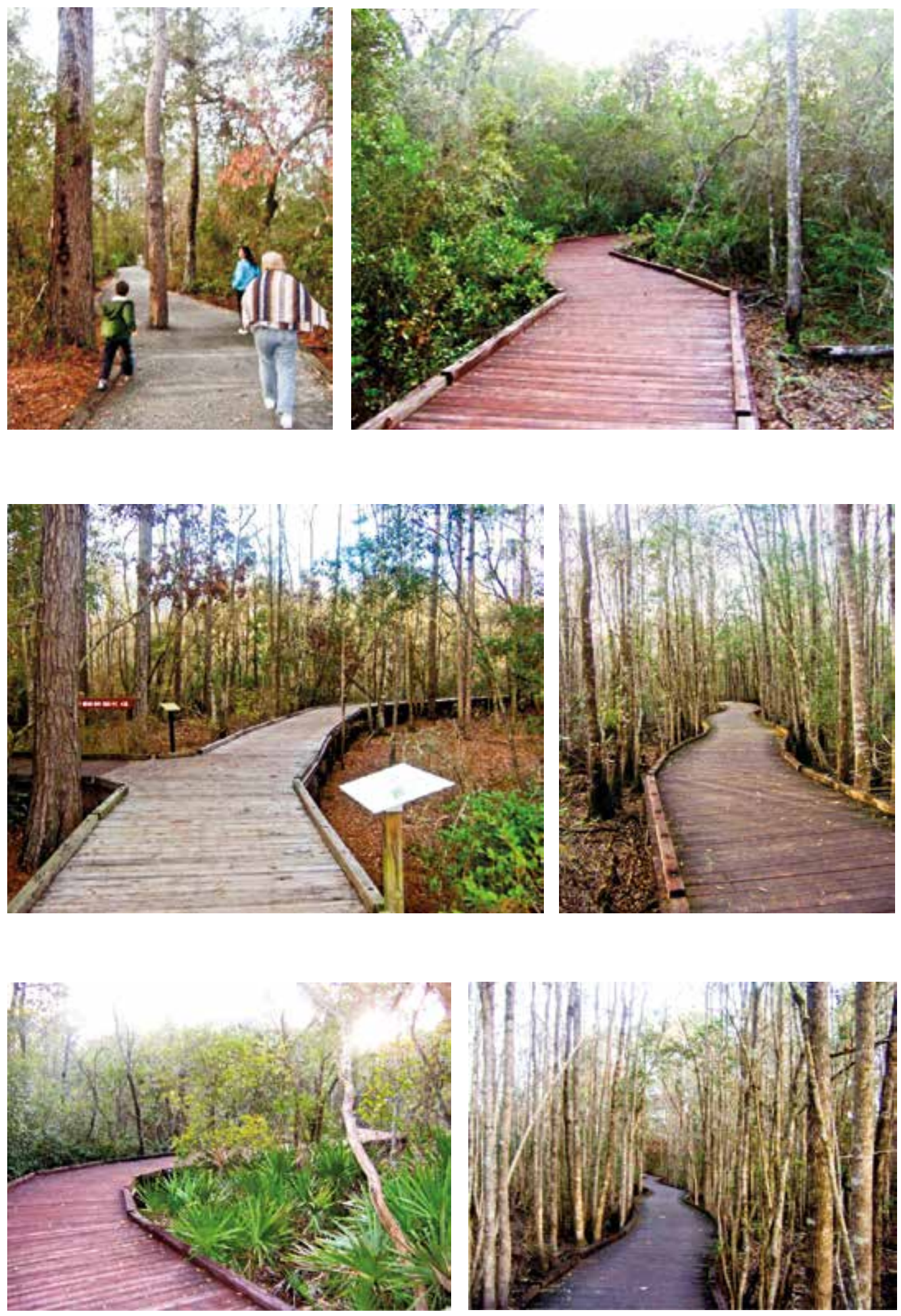

Figura 34: Trilhas naturais e passarelas elevadas de madeira para caminhada e contemplação da paisagem.

Estruturas físicas: equipamentos, mobiliários e material alternativo aplicados pelo projeto paisagístico. Infra-estrutura de apoio (passarelas sinuosas e placas informativas).

Okefenokee National Wildlife Refuge - Folkston - GA - USA

Fonte: Acervo pessoal Pippi, 2006 

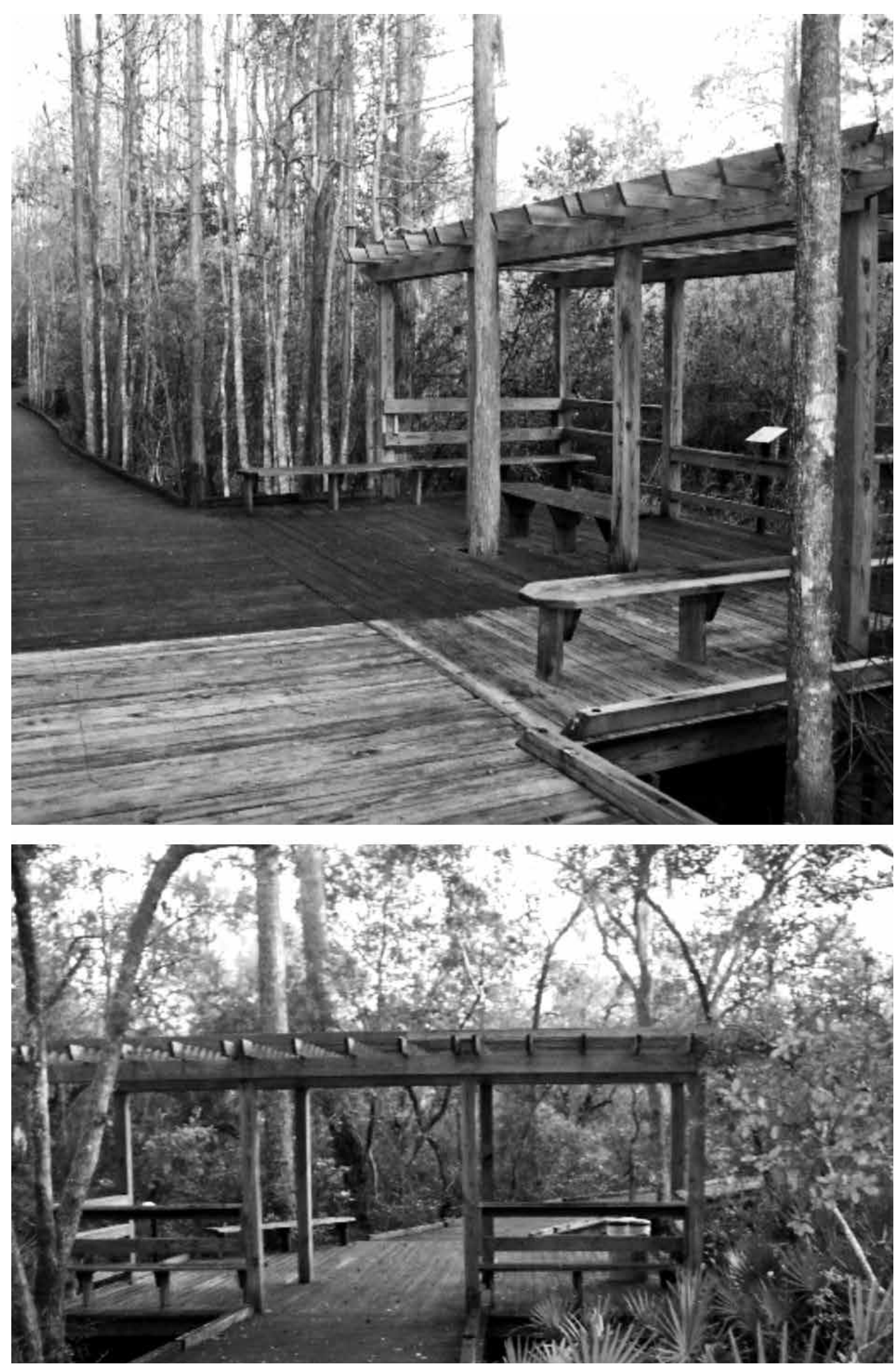

Figura 35: Recantos de estar para contemplação da paisagem, fauna e flora e estruturas físicas: equipamentos, mobiliários e material alternativo aplicados pelo projeto paisagístico (pergoldados/deck, banco, guarda-corpo e placas informativas. Okefenokee National Wildlife Refuge - Folkston - GA - USA Fonte: Acervo pessoal Pippi, 2006 
parques com estrutura física própria e recursos naturais com áreas de mata nativa/ matas ciliares, riachos, rios e formações rochosas, que constituem o respectivo parque linear. Suas estruturas físicas propiciam às práticas ecoturísticas a educação ambiental e a conservação e preservação de seus recursos naturais.

O parque Okefenokee National Wildlife Refuge, configurado por área de mangue e mata nativa, é um exemplo de conservação e preservação de seus ecossistemas, garantindo o hábitat, refúgio, alimento e a perpetuação de porções significativas da fauna e flora do estado da Geórgia. Suas estruturas físicas propiciam as práticas ecoturísticas, a educação ambiental, a leitura e contemplação de paisagens pantanosas exuberantes, onde é possível vislumbrar, ao longo das trilhas, passarelas, recantos projetados para observação e contemplação, passeios de barco e canoas, as espécies da flora: vegetação de mangue e áreas alagáveis e fauna: diversas aves, répteis e crustáceos, como veados, crocodilos, ursos pretos, entre outros.

\section{CONCLUSÃO}

A partir do conhecimento dos conceitos, objetivos, diretrizes, métodos de planejamento do espaço ecoturístico e alguns exemplos de intervenções, os profissionais dispõem de elementos que permitem destacar os atrativos paisagísticos mo meio natural.

O trabalho destaca, ainda, que se faz necessário o respeito à legislação ambiental vigente, bem como sua aplicação e fiscalização pelos órgãos competentes auxiliados pela comunidade, para, assim, garantir a harmonia e a sustentabilidade do meio ambiente. Precisamos utilizar o espaço de maneira organizada e integrada, tanto com a comunidade como com o meio ambiente, na tentativa de criar-se uma vida equilibrada baseada nos princípios ecológicos e seu equilíbrio.

Torna-se, portanto, imprescindível a participação do profissional técnico especialista no trabalho do planejamento da paisagem para com o ecoturismo e, conseqüentemente, para o meio ambiente. $\bigcirc$ planejamento paisagístico só poderá ser realizado por uma equipe multi e interdisciplinar envolvida com todos os elementos da paisagem a planejar. Isso porque, em seu planejamento integrado, devem ser considerados todos os elementos geobiofísicos e as estruturas socioeconômicas que a compõem.

Cabe ao arquiteto paisagista, integrante dessa equipe, a importante tarefa de síntese dos inventários e diagnósticos e o planejamento da paisagem, para garantir a integração social, ambiental e a conquista da cidadania, que só poderá ser conseguido após uma integração de equipes multidisciplinares, cujo conhecimento técnico é abordado em sua plenitude. $\bigcirc$ arquiteto paisagista tem a capacidade de buscar objetivo e estratégias mais sustentáveis e integradas às paisagens, ao planejar e projetar os ambientes e para a construção de edificações e de espaços livres mais sustentáveis, minimizando os impactos imediatos das áreas construídas para com o meio ambiente, ao mesmo tempo em que consegue considerar todos os aspectos sociais, econômicos, culturais e políticos envolvidos no processo.

Ambos os estudos de caso apresentados refletem a utilização dos conceitos paisa- 
gísticos na prática profissional em locais com potencialidades ecoturísticas, oferecendo subsídios para proposições ecologicamente corretas, em cada uma das etapas do projeto paisagístico. Os materiais alternativos, por sua vez, permitem garantir a integração, a flexibilidade, modulação, montagem, desmontagem e relocação dos elementos, sem deixar resíduos no ambiente, possibilitando garantir a manutenção dos elementos naturais e dos ecossistemas com o mínimo de impacto na paisagem e a promoção da educação ambiental.

Por outro lado, a educação ambiental e a capacitação dos técnicos envolvidos permitem que os diferentes usuários (locais e turistas) tenham informações suficientes para desfrutar do ambiente com responsabilidade, tornando-os mais um elemento responsável pela conservação e preservação dos espaços ecoturísticos.

\section{Bibliografia}

ABBUD, Benedito. Criando paisagens. Guia de trabalho em arquitetura paisagística. São Paulo: Senac, 2006.

ADAM, Roberto Sabatella. Princípios do ecoedifício: Interação entre ecologia, consciência e edifício. São Paulo: Aquariana, 2001.

BOULLÓN, Roberto. Planejamento do espaço turístico. Bauru-SP: Edusc, 2002.

CALDAS, Sérgio T. Nossos Pobres Parques. Revista Terra, São Paulo, 84 ed., ano 8, n. 4, 1999.

FIGUEIREDO, Luiz Afonso. Ecoturismo e Participação Popular no Manejo de Áreas Protegidas. In: RODRIGUES, Adir. Turismo e ambiente - Reflexões e propostas. São Paulo: Hucitec, 1997.

JOHNSON, Mark. Ecology and the Urban Aesthetic. In: THOMPSON, George, F.; STEINER, Frederick. R. Ecological design and planning. Nova York: John Wiley \& Sons, Inc., 1997.

LINDBERG, Kreg; HAWKINS, Donald E. Ecoturismo: Um guia para planejamento e gestão. São Paulo: Senac, 1999.

MACEDO , Silvio S. Paisagem, urbanização e litoral - Do Éden à cidade. 1993. Tese (Livre-docência) - Faculdade de Arquitetura e Urbanismo, Universidade de São Paulo, São Paulo, 1993.

Quadro do Paisagismo no Brasil. São Paulo: FAUUSP, 1999 (Coleção Quapá).

MACHADO, Ewerton Vieira. Turismo, paisagem e ambiente: ao viés do desenvolvimento sustentável - algumas notas como contribuição ao debate X. In: RODRIGUES, Adir. Turismo e ambiente - Reflexões e propostas. São Paulo: Hucitec, 1997.

RUANO, Miguel. Ecourbanismo entornos humanos sostenibles: 60 proyectos. Barcelona: Gustavo Gilli, 1999.

SATTLER, Miguel Aloysio. Edificações sustentáveis: Interface com a natureza do lugar. In: MENEGAT, Rualdo; ALMEIDA, Gerson (Org.). Desenvolvimento sustentável e gestão ambiental nas cidades: Estratégias a partir de Porto Alegre. Porto Alegre: Editora da UFRGS, 2004.

SITE EMBRATUR: Disponível em: <http: // www.embratur.gov.br >. Acesso em: 10 nov. 2005.

SPIRN, Anne W. The language of landscape. New Haven; Londres: Yale University, Press, 1998.

VIVEIROS, Mariana. 42\% dos Parques Nacionais estão fechados. Folha de São Paulo, São Paulo, 19 abr. 2003. Folha do Cotidiano (C1). 
